\title{
Emerging Contaminants in Seafront Zones. Environmental Impact and Analytical Approaches
}

\author{
José S. Câmara ${ }^{1,2, *(1)}$, Sarah Montesdeoca-Esponda ${ }^{3}{ }^{(D}$, Jorge Freitas ${ }^{1}\left(\mathbb{D}\right.$, Rayco Guedes-Alonso ${ }^{3}(\mathbb{D}$, \\ Zoraida Sosa-Ferrera ${ }^{3}$ (i) and Rosa Perestrelo ${ }^{1}$ (i) \\ 1 CQM-Centro de Química da Madeira, Campus Universitário da Penteada, 9020-105 Funchal, Portugal; \\ jorge.freitas@staff.uma.pt (J.F.); rmp@staff.uma.pt (R.P.) \\ 2 Departamento de Química, Faculdade de Ciências Exatas e Engenharia, Universidade da Madeira, \\ Campus da Penteada, 9020-105 Funchal, Portugal \\ 3 Instituto Universitario de Estudios Ambientales y Recursos Naturales (i-UNAT), \\ Universidad de Las Palmas de Gran Canaria, 35017 Las Palmas de Gran Canaria, Spain; \\ sarah.montesdeoca@ulpgc.es (S.M.-E.); rayco.guedes@ulpgc.es (R.G.-A.); zoraida.sosa@ulpgc.es (Z.S.-F.) \\ * Correspondence: jsc@staff.uma.pt; Tel.: +351-291705112
}

Citation: Câmara, J.S.;

Montesdeoca-Esponda, S.; Freitas, J.; Guedes-Alonso, R.; Sosa-Ferrera, Z.; Perestrelo, R. Emerging

Contaminants in Seafront Zones.

Environmental Impact and Analytical Approaches. Separations 2021, 8, 95. https://doi.org/10.3390/ separations 8070095

Academic Editors: Virgínia

Cruz Fernandes and

Cristina Delerue-Matos

Received: 10 May 2021

Accepted: 28 June 2021

Published: 1 July 2021

Publisher's Note: MDPI stays neutral with regard to jurisdictional claims in published maps and institutional affiliations.

Copyright: (c) 2021 by the authors. Licensee MDPI, Basel, Switzerland. This article is an open access article distributed under the terms and conditions of the Creative Commons Attribution (CC BY) license (https:// creativecommons.org/licenses/by/ $4.0 /)$.

\begin{abstract}
Some chemical substances have the potential to enter the coastal and marine environment and cause adverse effects on ecosystems, biodiversity and human health. For a large majority of them, their fate and effects are poorly understood as well as their use still unregulated. Finding effective and sustainable strategies for the identification of these emerging and/or anthropogenic contaminants that might cause polluting effects in marine environments to mitigate their adverse effects, is of utmost importance and a great challenge for managers, regulators and researchers. In this review we will evaluate the impact of emerging contaminants (ECs) on marine coastal zones namely in their ecosystems and biodiversity, highlighting the potential risks of organic pollutants, pharmaceuticals and personal care products. Emerging microextraction techniques and high-resolution analytical platforms used in isolation, identification and quantification of ECs will be also reviewed.
\end{abstract}

Keywords: emerging contaminants; marine zones; environment; seafront waters; microextraction techniques; analytical platforms

\section{Introduction}

As the United Nations stated in the Ocean Conference of 2017,40\% of the world's population live within $100 \mathrm{~km}$ of the coast and $25 \%$ of them in coastal areas that are less than $10 \mathrm{~m}$ above sea [1]. Coastal areas have an important impact over global economy being the recipient places of approximately $50 \%$ of international tourists. The biodiversity of marine ecosystems is also crucial, as they are home to approximately 2 million known species, which may be $9 \%$ of all marine species [2]. Nevertheless, the combined effect of growing populations and economic development constitutes threatening the same coastal and marine ecosystems [3].

Numerous pollutants can reach coastal areas due to human activity in these places. However, these areas are not only affected by the activities that take place there. Some studies establish that up to $80 \%$ of the pollution of seas and oceans comes from land-based activities [1]. For decades there has been much research studying the contamination of coastal ecosystems by chemical pollutants of various characteristics. One example is the study of Berne et al. (1980) in which the authors studied the effect of the pollution cause by hydrocarbons from oil spilled on the Brittany coast by Amoco Cadiz in 1978 [4]. Furthermore, in the last decades, a growing scientific concern has arisen around the presence and effects of emerging pollutants in the environment [5-8]. These pollutants are defined as both naturally and synthetic occurring chemicals that are not included in monitoring or surveillance programs and, subsequently, they are not comprised in environmental legislation. However, these pollutants are suspected to produce toxic effects over ecosystems or 
human health. The presence of emerging contaminants (ECs) in the environment is not necessarily new, however, it has only in recent years, with the implementation of high resolution and highly sensitive analytical methodologies that it was possible to identify many of them [5-7]. in addition, the continuous development of chemical compounds, as well as their uses and disposal, produce new sources of emerging pollutants [8].

From the variety of emerging pollutants, pharmaceuticals and personal care products (PPCPs) are a very important group due to their wide and continuous use in our life. Pharmaceutical compounds (PhaCs) comprise a great group of chemical substances with varied uses, consumption trends and physicochemical properties, which means many distribution behaviors when reach the ecosystems. Nowadays, more than 600 PhaCs have been shown to be present in the environment worldwide [9]. Regarding personal care products (PCPs), this group is formed by also a wide group of chemicals such as UV filters and stabilizers, musks, preservatives or disinfectants which are used in products to improve the quality of daily life [10]. The extensive and increasing use of PPCPs has produced that these compounds become a major concern due to their continuous release to the environment, resulting in a pseudo-persistence of them [11]. Wastewater treatment plants (WWTPs) are the main source of PPCPs in the environment, due to they are not designed to eliminate these emerging contaminants (ECs). For these reasons, many studies are focused in the assessment of PCPs in coastal areas affected by the effluents of WWTPs, where these compounds could be present at concentrations ranging from ng. $\mathrm{L}^{-1}$ to $\mu \mathrm{g} \cdot \mathrm{L}^{-1}[12,13]$. Other pathways considered by regulatory risk assessment approaches include livestock and aquaculture facilities, runoff from fields or inappropriate disposal of unused medicines and personal care products $[10,11]$.

The assessment of PPCP concentrations is necessary to evaluate the environmental health of coastal and marine ecosystems because these compounds could produce many biological effects on marine biota [14] from subcellular or cellular to organismal-levels. These effects affect vital functions as reproduction, growth, metabolism, immunity, feeding and locomotion depending on the properties of PPCPs [15]. This work covers scientific papers published from 2010 to 2021 that study the presence of PPCPs in coastal areas worldwide and review several aspects of PPCPs after reaching the environment such as (i) the occurrence of PhaCs in the different coastal ecosystems, (ii) the environmental impact and risk assessment of PPCPs and (iii) the analytical platforms to identify and determine these ECs in samples from coastal origin. This review provides information collected from three databases, namely Scopus, Science Direct and Publons. The keywords used to perform the selection include "emerging contaminants", "pharmaceuticals and personal care products", "coastal environment", "extraction techniques" and "high resolution analytical platforms".

\section{Emerging Contaminants in Marine Coastal Zones}

Aquatic ecosystems are the source and support of most of life on Earth. They also encompass a diverse range of direct or indirect services and goods deemed as essential for human activities. They include food provision, energy, mineral resources, transportation routes, recreational activities and ecological functions (e.g., climate systems). Therefore, all aquatic ecosystems are subject to multiple pressures, competing for usage and impacts derived from human activities, being necessary to develop strategies to protect and maintain, its capacity to continuing the delivery of such services [16].

The European Union (EU), under the strategy of the European Green Deal, devised a set of policies to achieve its ambition of protection and restoration of biodiversity as well, climate neutrality. The main policies related to aquatic ecosystems are the Marine Strategy Framework Directive3 (MSFD) [17] and the Water Framework Directive (WFD) [18]. Both give high relevance to the monitoring and control of pollutants and substances with the potential to pollute. The MSFD and the WFD were designed as a holistic policy to protect marine and freshwater environments around Europe and enable their sustainable use of goods and services. In the specific case of marine coastal zones, there is an overlap 
between both directives, since the main source of contaminants in marine environments are originated in land-based facilities and from freshwater systems [19].

The use of synthetical and natural chemical compounds has become an essential commodity for food production, health care, sanitation and daily life [20]. After use and disposal, these contaminants spread through the aquatic systems (freshwater and marine environments) causing stress effects on different organisms and communities. This occurrence is capable to disrupt an ecosystem function, due to their persistent, toxic and bioaccumulative effect [21], and/or inefficiency of the wastewater treatment plants in dealing with such contaminants [22]. However, there are also cases in which such anthropogenic contaminants are emitted or re-emerge directly from the marine environment. One of the main activities that may lead to environmental pollution is the maritime transport of Hazardous and Noxious Substances (HNS), which englobe all the chemical substances that are introduced in the marine environment, that pose risks to the environment, human health and activities. Even though these are listed and controlled substances, the amount of data on their toxicity and environmental impact is less understood than oil spills [23]. Other than accidental spills, operational discharges (e.g., chemicals or passenger ships) and the use of antifoul paints are also responsible for the introduction of a chemical substance in the marine environment. Furthermore, mariculture (e.g., antibiotics), offshore activities (e.g., oil and gas exploration), seabed mining and dredging of sediments, are all events capable to contribute to the input of chemical substances in the marine environment [24].

The main pollutants can be divided into two groups, legacy contaminants and contaminants of emerging concern (CEC) [25]. The first encompasses the traditional monitored hazardous substances such as inorganic pollutants as heavy metals (e.g., mercury, lead), radionuclides (e.g., ${ }^{137} \mathrm{Cs}$ ) and organic pollutants (e.g., polychlorinated biphenyls (PCBs), polycyclic aromatic hydrocarbons (PAHs)). The second is defined as "chemicals that have been detected in the environment, but which are currently not included in regulatory monitoring programs and whose fate and biological impacts are poorly understood" [26].

CECs include substances that are not regulated by EPA or EU Norman network including a diverse range of chemicals and their sub-products that are classified under a variety of group categories. The most common groups are flame retardants, antifoulants, anticorrosion agents, polyfluoroalkyl substances other than PFOS and PFOA, benzotriazoles or siloxanes [19]; also, pharmaceuticals, antibiotics, personal care products and illicit drugs [27-30], as well as, microplastics, trace metals, nanomaterials and pesticides [31,32]. While PhaCs have been the most prominent emerging pollutants for decades, PCPs have gained great attention in the last 5-10 years, given the wide and varied use of daily care products by the population. Thus, the focus is nowadays put on compounds such as parabens or UV filters, which are widely added to PCPs due to their benefits, but whose adverse effects are becoming worrying. In this work, in the following subsections, special attention will be given to PhaCs and PCPs.

\subsection{Pharmaceuticals}

Since the introduction in 1897 of the first synthetic pharmaceutical, Aspirin, incredible advances in drugs for a wide range of health concerns were observed. Since all over the world the number of PhaCs for veterinary and medical health care, as well as growth promotion of livestock, reaches a few thousand, designed for the diagnosis, treatment or prevention of disease and for restoring, correcting or modifying organic functions through the interaction with specific physiological pathways of targeted organisms. Once reaching the marine ecosystems, they may cause a risk to the health of marine organisms acting as stressors on marine ecosystems already impacted by eutrophication, overfishing and climate changes [33]. Different classes and nature of PhaCs, including antibiotics, $\beta$-blockers, anti-inflammatories, antiepileptics, lipid lowering agents and antidepressants, lipid lowering agents, are presented in Table 1. 
Table 1. Example of some classes and nature of PhaCs.

\begin{tabular}{|c|c|c|c|}
\hline Nature of Drug & & & Drug \\
\hline Hydrophilic & \multirow{3}{*}{ Antibiotics } & Quinolones & Ciprofloxacin, Levofloxacin \\
\hline Hydrophilic & & Streptogramins & Pristinamycin IA and IIA \\
\hline Hydrophilic & & Oxazolidinones & Linezolid, Tedizolid \\
\hline Hydrophilic & \multirow{3}{*}{$\beta$-Blockers } & 1st $\mathrm{G}^{\mathrm{a}}$ & Propranolol, Timolol \\
\hline Hydrophilic & & 2nd G & Metoprolol, Atenolol \\
\hline Hydrophilic & & 3th G & Carvedilol, Bucindolol \\
\hline Hydrophilic & \multirow{4}{*}{\multicolumn{2}{|c|}{ Anti-inflammatory }} & Aspirin \\
\hline Varies & & & Diclofenac \\
\hline Moderate hydrophobic & & & Ibuprofen \\
\hline Hydrophilic & & & Acetaminophen \\
\hline Hydrophobic & \multirow{3}{*}{ Antiepileptics } & Barbiturates & Phenobarbitone \\
\hline Moderate hydrophobic & & Imunostilbene & Carbamazepine \\
\hline Hydrophilic & & Aliphatic $\mathrm{CA}^{\mathrm{b}}$ & Valproate \\
\hline Hydrophobic & \multirow{3}{*}{\multicolumn{2}{|c|}{ Lipid regulators }} & Atorvastatin \\
\hline Hydrophobic & & & Simvastatin \\
\hline Hydrophilic & & & Rosuvastatin \\
\hline Moderate hydrophobic & \multirow{3}{*}{ Antidepressants } & SSRIs $^{c}$ & Sertraline; Fluoxetine, \\
\hline Hydrophobic & & TCAs $^{\mathrm{d}}$ & Amoxapine, Amitriptyline \\
\hline Hydrophobic & & MAOIs e & Isocarboxazide, Phenelzine \\
\hline
\end{tabular}

${ }^{a}$ G-Generation; ${ }^{b}$ CA-carboxylic acid; ${ }^{c}$ SSRIs-selective serotonin reuptake inhibitors; ${ }^{\mathrm{d}}$ TCAs-Tricyclic antidepressants; ${ }^{\text {e }}$ MAOIsmonoamine oxidase inhibitors.

PhaCs have been detected in water resources and aquatic organisms. Various routes, such as excretion and discharge into sewage systems on a continual basis, discharge of effluent directly into river bodies by the manufacturing plant facilities, landfill leachate, industrial effluent, combined sewer overflows, aquaculture facilities- up to $75 \%$ of the administered dietary dose of a veterinary medicine, including antibiotics, can be lost to the surrounding environment [34], animal feedlots and veterinary practices [35], constitute important vectors for entry of PhaCs in environment and aquatic systems (Figure 1).

Being poorly removed by treatment plants and slowly degraded, increased threats derived from increasing trends in urbanization and commercial activity. Martínez et al. [36] reported that over 2.3 billion people live within coastal limits (representing $41 \%$ of world global population) and more than $50 \%$ of coastal countries have $80-100 \%$ of their total population within $100 \mathrm{~km}$ of the coastline [37]. According to Gaw et al. [37] "these trends suggest the potential for increasing inputs of human pharmaceuticals into coastal environments and therefore the need to address potential exposure scenarios and implications for marine risk assessments of drug residues and their transformation products" [37].

Even though found at very low levels (from a few $\mathrm{ng} \mathrm{L^{-1 }}$ to $\mu \mathrm{g} \mathrm{L}^{-1}$ ) in the coastal marine zones, their continuous release is a matter of much concern, namely due to the synergistic action resulting from the simultaneous coexistence of different classes of PhaCs, as well as more recently bound to sediment and plastic particles (typically $\mathrm{ng} \mathrm{g}^{-1}$ ).

Globally the volume of used medicines reached 4.5 trillion of doses by 2020 with about $50 \%$ of the world population consuming more than one dose per person per day [38]. In Portugal the consumption of antidepressants and anxiolytics is increasing. Two different studies revealed that in 2018 about 25,000 packs of antidepressants were sold per day. On the other hand, medications for anxiety and for the regularization of sleep are part of the life of one-quarter of the Portuguese population. In last year, due to COVID-19 pandemics, it is estimated that this number has increased significantly, in terms of volume and value, accompanied by the increased market share of generic medicines (Figure 2). 


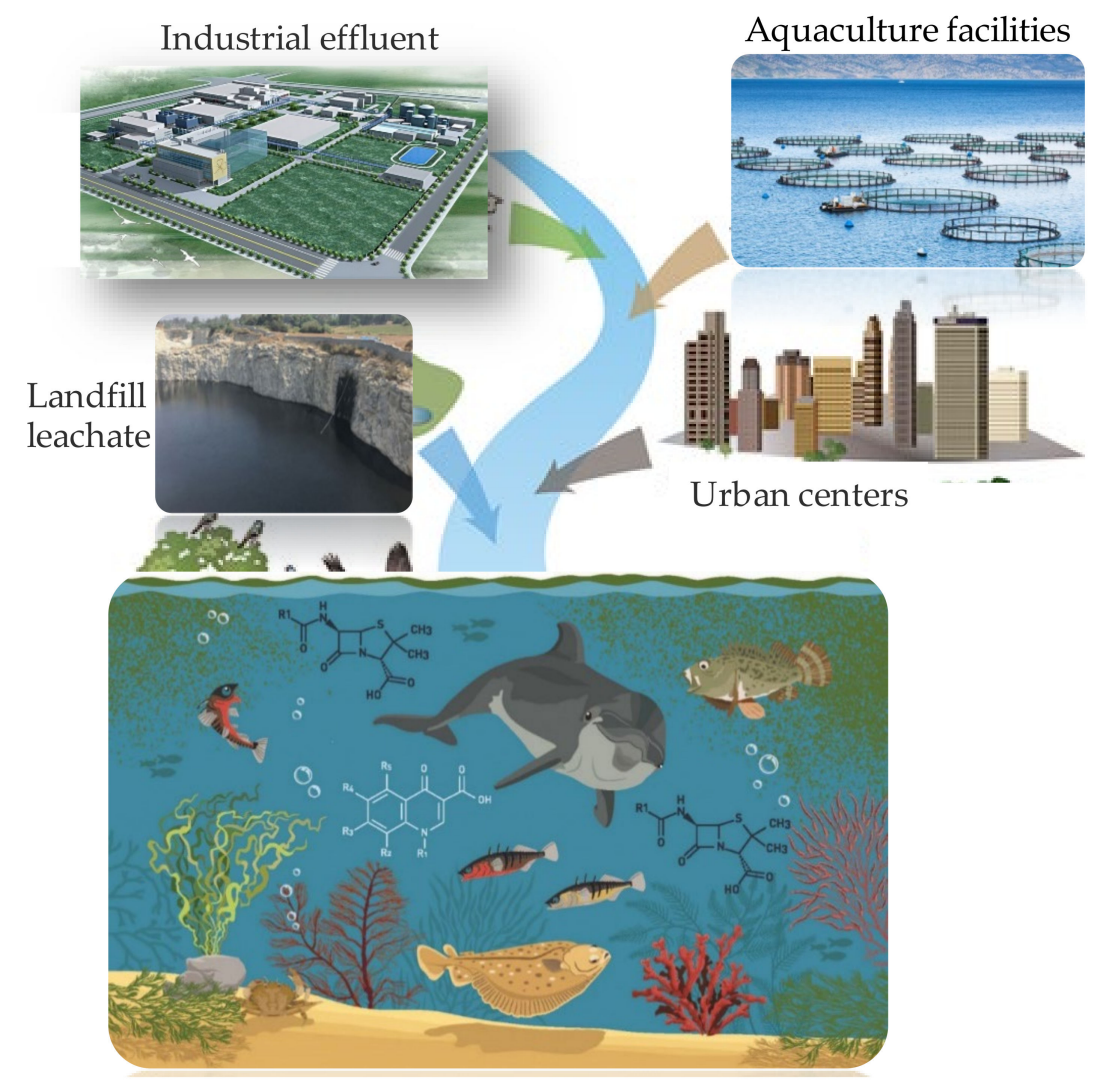

Figure 1. Typical sources PhaCs and PCPs aquatic systems.

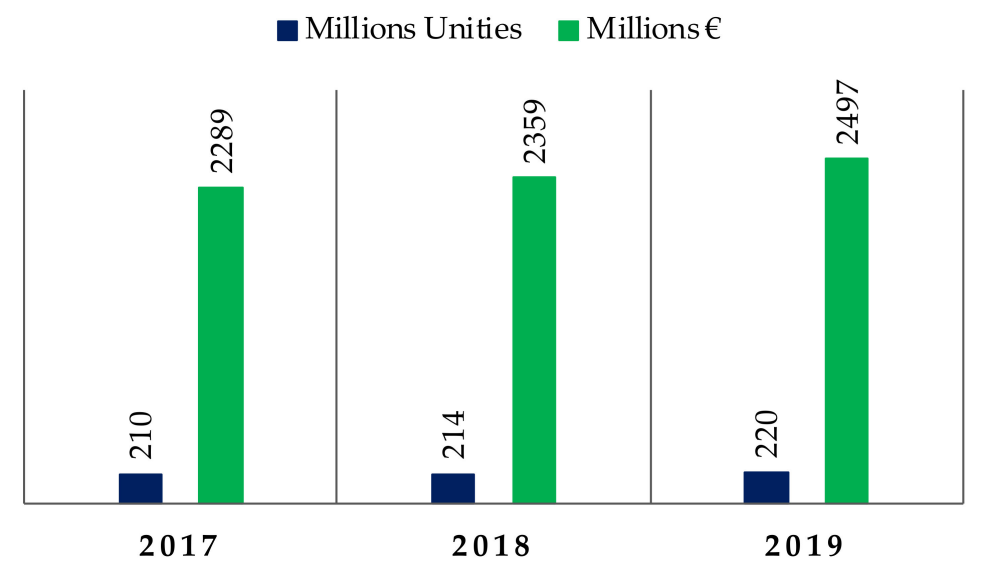

Figure 2. PhaCs evolution in Portugal between 2017-2019.

Compared with 2018, there is an increase of the number of antidiabetics, analgesics and active agent in renin-angiotensin sold (A10, N02 and C09 anatomical therapeutic chemical (ATC) classes). The growth observed in medicine classes used to treat conditions such as diabetes, pain and cardiovascular diseases is in line with the prevalence of these chronic diseases in Portugal. The growth observed between 2018 and 2019 is based on the increase in the value of generic $(€ 29 \mathrm{M})$ and branded medicines $(€ 108 \mathrm{M})$. Simvastatin + Ezetimibe and Atomoxetine generics had the highest penetration rate, reaching a market share of around $52 \%$ in sell-out counting units.

\subsection{Personal Care Products}

Used in cosmetics and daily care products including preservatives, residues of surfactants used in detergents and soaps, fragrances, synthetic musks, UV-filters (e.g., benzophe- 
none, octocrylene) and plasticizers used in product packaging and linings (e.g., bisphenol A, BPA), PCPs constitute an important class of emerging contaminants, with great impact on aquatic organisms. In addition to present at trace levels (from ng. $\mathrm{L}^{-1}$ to $\mu \mathrm{g} \cdot \mathrm{L}^{-1}$ ) exert toxicological effects (e.g., endocrine disruptors) enhanced by high bioaccumulation potential and persistence in the environment [39]. Therefore, most of PhaCs and PCPs have become continuously present (pseudo-persistent) in the marine ecosystem [40].

Belonging to different chemical families, such as benzimidazoles, camphor derivatives, triazines, benzotriazoles, cinnamates, salicylates benzophenones, p-aminobenzoates, UV filters were used to protect skin from UV solar radiation. They are usually soluble in fatty matrices, although some of them contain ionizable moieties, such as carboxylate (-COOH) or sulphonic $\left(-\mathrm{SO}_{3} \mathrm{H}\right)$, which enables their solubility in water. Its absorption through the skin followed by metabolization and bioaccumulation, depending on chemical nature of the UV filter, might raise several health-related serious concerns including estrogenic and carcinogenic activity [41,42]. In addition, ECs can easily reach aquatic environments and therefore marine coastal zones, and even present at very low levels, ng $\mathrm{L}^{-1}$, they can accumulate in these systems and cause harmful effects in flora and fauna. Contrary to PhaCs which are metabolized by the organism, some of these PCPs are not easily metabolized and, therefore, its regular use leads to the presence of large quantities in the environment and particularly in the aquatic systems [43]. Relatively to fragrances, namely synthetic musks (either nitro musks or polycyclic musks), are used in a wide range of products (e.g., soaps, deodorants, detergents), and for this reason is commonly found in aquatic organism, air, human milk, blood and adipose tissues. This fact resulting in the potential adverse effects on ecological environmental (e.g., PPCPs degradation products) and human health (e.g., cancer) [44].

Some studies reported the levels of ECs, namely PhaCs and PCPs, in marine biota, sea water and sediments (Table 2) reflecting both (i) the poor efficiency of the wastewater treatment plants, and (ii) the anthropogenic activity. In addition, some PCPs are used in large quantities, and recent works have indicated that many of them are bioactive, have the potential for bioaccumulation and are environmentally persistent $[45,46]$.

Table 2. Levels of PhaCs and PCPs in marine environment.

\begin{tabular}{|c|c|c|c|c|c|}
\hline \multirow{2}{*}{ Region } & \multicolumn{4}{|c|}{ PhaCs (ng/L) } & \multirow[t]{2}{*}{ Reference } \\
\hline & $\mathrm{DCF}^{\mathrm{a}}$ & $\mathrm{CMP}^{\mathrm{b}}$ & AAP $^{c}$ & SMA ${ }^{d}$ & \\
\hline Red Sea & $\mathrm{nd}^{\mathrm{e}}$ & 3.8 & 16.7 & nd & [47] \\
\hline Baltic Sea & nd & $0.6-3.2$ & nd & nd & [47] \\
\hline Yellow Sea & nd & na & nd & 7.7 & [47] \\
\hline Mediterranean Sea & nd & $0.004-0.013$ & $0.03-0.11$ & nd & [47] \\
\hline Gulf of Cadiz & nd-2.5 & nd-0.1 & nd-2.8 & nd & [47] \\
\hline Brazilian coastal & & & & & [47] \\
\hline False Bay & $2.6-3.7$ & $0.7-1.6$ & $0.9-1.9$ & $0.3-4.8$ & [47] \\
\hline \multirow[t]{3}{*}{ Bohai Bay } & nd & nd & nd & $2.3-140$ & [47] \\
\hline & \multicolumn{4}{|c|}{ PCPs (ng/L) } & \\
\hline & PAR $^{f}$ & TCS $\mathrm{g}$ & $4 \mathrm{MBC}^{\mathrm{h}}$ & $\mathbf{M K}^{\mathrm{i}}$ & \\
\hline United States ${ }^{j}$ & $14-400$ & $<0.1-2300$ & $2.3-545$ & $4.8-390$ & [48] \\
\hline Brazil $^{l}$ & nd & nd & $11.6-17.1$ & nd & [49] \\
\hline Philippines $\mathrm{m}$ & nd & $0.29-2.0$ & nd & nd & [50] \\
\hline
\end{tabular}

a DCF-Diclofenac; ${ }^{\mathrm{b}} \mathrm{CMP}-$ carbamazepine; ${ }^{\mathrm{c}} \mathrm{AAP}-$ Acetaminophen; ${ }^{\mathrm{d}} \mathrm{SMA}-$ Sulfamethoxazole; ${ }^{\mathrm{e}}$ nd-not detected; ${ }^{\mathrm{f}}$ PAR-Paraben; ${ }^{\mathrm{g}} \mathrm{TCS}$-Triclosan; ${ }^{\mathrm{h}}$ 4MBC—4-methyl-benzilidine-camphor; ${ }^{\mathrm{i}}$ MK-Musk ketone; j Surface water, ${ }^{1}$ Marine biota; ${ }^{\mathrm{m}}$ Surface water. 


\section{Environmental Impact and Risk Assessment}

The presence of some PhaCs and PCPs in the environment have been already found as toxic and harmful for the marine organisms. In the literature, negative effects for different kinds of biota, from small plankton to big mammals, are widely described for many emerging compounds.

PhaCs undergo metabolic transformation within the human and animal bodies and some metabolites may potentially pose greater risk than the original substances [51]. Contrary, some of these PCPs are not subjected to metabolic alterations, large quantities of them enter the environment unaltered [43].

The chemical characteristics of the pollutants are determinant in the extent of the injury caused to the environment. For example, the more hydrosoluble the compounds, the more bioavailable they are to phytoplankton [52]. Surrounding pollutants can affect species differently because their routes of exposure depending on the food preferences of marine organisms [53]. Thus, filter feeders or detritivores individuals can easily bioaccumulate pollutants directly from media while large carnivores can biomagnify the compounds very quickly. Bioaccumulation and biomagnification processes depends on several aspects such as age, weight, sex, diet, metabolic activity, habitat, content of proteins and lipids, seasons, growth and reproduction rates, migrations, etc. [54].

Both PhaCs and PCPs could act as endocrine disruptors for marine organisms [55]. Most of the detected impacts or damages are related with alteration of reproductive capability, problems of growth and decrease of survival rates and these negative effects have been reported even at trace concentrations $\left(\mathrm{ng} \mathrm{L}^{-1}\right)$.

For example, antineoplastic drugs used against cancer diseases are responsible to cause changes in the reproductive function, oxidative stress, genotoxicity, cytotoxicity and neurotoxicity [56]. Widely used analgesics (e.g., paracetamol) are systematically reported to occur in the wild, where they may exert effects on oxidative stress biomarkers [57-59].

Otherwise, PCPs such as UV filters added to sunscreens may inhibit growth on some specific algae [60] or cause decrease on reproduction and increase of mortality in invertebrates [61]. Other important effect of UV filters is coral bleaching [62], which is very worrying since coral reefs are ecosystems with huge biodiversity. For this reason, some UV filters have been banned in some places such as Hawaii [63]. Others PCPs such as parabens are able to activate several nuclear receptors causing changes in hormones-dependent signalling pathways [64].

Some papers have also studied the relation between the risk associated to the presence of some emerging pollutants and the ocean acidification because of the climate change [65-69]. The study of Mezzelani et al. (2021) revealed clearly increased cellular hazard for mussels due to interactions of carbamazepine with acidification compared to single stressors [65].

In addition to the individual effects of these analytes, there is a growing concern about the potential adverse consequences of the interactions among the substances when they are simultaneously present in the environment [70]. Moreover, it should be considered that the knowledge is still limited to a few model species, while there are many groups of organisms completely unexplored regarding the effects of emerging pollutants [71].

According to the Technical Guidance Document on Risk Assessment from the EU [72], there are three main approaches to assess the potential risk from the presence of individual pollutants in the aquatic environment: (i) a quantitative approach based on predicted or measured environmental concentration, (ii) a qualitative approach applied when a quantitative estimate of the exposure and/or effects of a substance are not possible and (iii) the Persistence, Bioaccumulation, Toxicity (PBT) assessment [73]. The most desirable scenario is to have data to evaluate environmental risks in a quantitative way. With this purpose, the Hazard Quotients (HQs), also called Risk Quotients (RQs), are usually estimated, following the European Medicines Agency (EMEA) guidelines [74]. HQ is defined as:

$$
\mathrm{HQ}=\mathrm{MEC} / \mathrm{PNEC}
$$


where MEC is the measured environmental concentration and PNEC is the predicted no-effect concentration, which is calculated based on chronic toxicity values [75].

Normally the maximum individual concentration found of each studied is used as MEC. When PNEC is not available, estimated PNECs can be derived from the values of $\mathrm{EC}_{50}$ (50\% effect concentration, that means concentration causing toxic effects in $50 \%$ of the organisms tested) or $\mathrm{LC}_{50}(50 \%$ lethal concentration) reported in the literature, divided by an appropriate uncertainty factor (assessment factor, AF), which varies from $10[66,76]$ to $1000[67,77]$. AFs are applied to adjust the differences between laboratory data and natural conditions, considering the distinction of interspecies and intraspecies. AFs used for longterm tests are smaller, since the uncertainty of the extrapolation from labs to the natural environment is lower. More data on more species in the same environmental compartment can also minimize uncertainties, consequently decreasing the AFs. $\mathrm{HQ}<0.1$ meaning minimum risk; $0.1 \leq \mathrm{HQ}<1.0$ meaning intermediate risk and $\mathrm{HQ} \geq 1.0$ meaning high environmental risk [76]. This approach allows becoming closer to the acute toxicity values in a situation in the natural media with longer exposure periods (chronic toxicity) [78].

The reliable estimation of HQ is therefore subjected to the available toxic information. Traditional ecotoxicity testing strategies for in vivo experiments are expensive, timeconsuming and reliant on large number of animal subjects, so it is not possible to test acute toxicity for all the chemicals used globally. For this reason, tools for ecotoxicity assessments have been developed, such as Quantitative Structure-Activity Relationships (QSAR), which uses a mathematical model to make a prediction. The model is built from physicochemical properties, such as molecular weight, octanol water partition coefficient $\left(\mathrm{K}_{\mathrm{ow}}\right)$, quantum mechanics calculations or presence of functional groups [79]. ECOSAR is a software from the U.S. Environmental Protection Agency (EPA) used to estimate the toxicity of chemical substances to freshwater organisms, specifically to daphnid, green algae and fish. This approach is limited but often used due to the scarce toxicity test data on marine aquatic species, especially for emerging contaminants. Even though a reasonable correlation exists between the ecotoxicological responses of freshwater and saltwater biota [80], it should considered that environmental concentrations of pollutants do not affect the different aquatic organisms in the same way [68].

Regrettably, the literature assessing the environmental risk of emerging pollutants in coastal ecosystem is not extensive. Table 3 shows a summary of HQs calculated for pharmaceuticals and personal care products in seafront zones when they result in intermediate $(0.1 \leq \mathrm{HQ}<1.0)$ or high environmental risk $(\mathrm{HQ} \geq 1.0)$.

Using ECOSAR approach, HQ values has been estimated for different PhaCs and PCPs found in coastal matrices. 32 PhaCs and PCPs were evaluated in the Albufera Natural Park (Valencia, Spain) in Mediterranean coast [66]. HQs were calculated for three mentioned trophic levels, and at the mean concentration, intermediate risk was registered only for caffeine in algae. However, at the maximum concentration, HQ of caffeine was higher than 1 for algae and tramadol showed an intermediate risk for the all the studied trophic levels. Since the samples presented a mixture of several compounds, the authors also evaluated the risk for the entire mixture by summing the ratios of each component, resulting that water was safe for daphnia and fish but not for algae.

A great multiresidual antibiotic analysis was performed for the study of 77 compounds (sulfonamides, quinolones, macrolides, lincomycins, $\beta$-lactam and tetracyclines) in three bays of the East China Sea. Even though the exact data are not provided, authors concluded that calculated risk for daphnid, green algae and fish revealed that the joint toxicity was enhanced when multiple antibiotics were present simultaneously. Thus, the sum of the HQ values of each antibiotic results in more sampling sites in acute and chronic toxicity risks. Moreover, an increase in the risk was observed from offshore to nearshore [81]. 
Table 3. Intermediate risk $(0.1 \leq \mathrm{HQ}<1.0)$ or high environmental risk (HQs $\geq 1.0)$ found for pharmaceuticals and personal care products in seafront zones.

\begin{tabular}{|c|c|c|c|c|}
\hline Location & Compound & Organism & $\mathrm{HQ}^{\mathrm{a}}$ & Reference \\
\hline \multirow{4}{*}{$\begin{array}{l}\text { Albufera Natural Park } \\
\text { (Spain) }\end{array}$} & Caffeine & Green algae & $\geq 1.0$ & \multirow{4}{*}[66]{} \\
\hline & \multirow{3}{*}{ Tramadol } & Green algae & $\geq 0.1$ & \\
\hline & & Daphnia magna & $<1.0$ & \\
\hline & & Fish & (not specified) & \\
\hline \multirow{2}{*}{ Port Philip Bay (Australia) } & Octocrylene & \multirow{2}{*}{ Not specified } & 3 & \multirow{2}{*}[83]{} \\
\hline & 2-ethylhexyl-4-methoxycinnamate & & 4 & \\
\hline \multirow{2}{*}{ Gran Canaria island (Spain) } & \multirow{2}{*}{ UV-327 } & Green algae & 0.298 & \multirow{2}{*}[84]{} \\
\hline & & Daphnia magna & $0.129-0.687$ & \\
\hline \multirow{3}{*}{ Cádiz Bay (Spain) } & Ibuprofen & \multirow{3}{*}{ Green algae Daphnia magna Fish } & 0.30 & \multirow{3}{*}[68]{} \\
\hline & Phenazone & & 0.28 & \\
\hline & Salicylic acid & & 0.48 & \\
\hline \multirow{8}{*}{ Pego-Oliva marsh (Spain) } & Acetaminophen & Daphnia magna & 0.321 & \multirow{8}{*}[82]{} \\
\hline & Ciprofloxacin & Green algae & 5.926 & \\
\hline & Diclofenac & Fish & 0.3 & \\
\hline & Ibuprofen & Fish & 1.2 & \\
\hline & Norfloxacin & Green algae & 0.978 & \\
\hline & Ofloxacin & Green algae & 3.137 & \\
\hline & Propanolol & Fish & 0.666 & \\
\hline & Sulfamethoxazole & Green algae & 0.581 & \\
\hline \multirow{4}{*}{ Biscayne Bay (USA) } & Estrone & \multirow{4}{*}{ Not specified } & $1.2-21.2$ & \multirow{4}{*}[55]{} \\
\hline & 17- $\beta$-estradiol & & $1.6-103$ & \\
\hline & Estriol & & $0.1-2.2$ & \\
\hline & 17- $\alpha$-ethynylestradiol & & $0.1-651$ & \\
\hline \multirow{3}{*}{ Capbreton Canyon (France) } & $\begin{array}{l}\text { 3-(4-methylbenzylidene)camphor } \\
\text { (4-MBC) }\end{array}$ & Green algae Daphnia magna Fish & $0.1-2.5$ & \multirow{3}{*}[85]{} \\
\hline & $\begin{array}{l}\text { 2-ethylhexyl 4-methoxycinnamate } \\
\text { (EHMC) }\end{array}$ & Potam. antipodarum & $0.19-39.7$ & \\
\hline & Octrocrylene & Green algae Daphnia magna Fish & 0.16 & \\
\hline Guarujá (Brazil) & Diclofenac & Danio rerio & 0.11 & {$[80]$} \\
\hline \multirow{4}{*}{ Santos Bay (Brazil) } & \multirow[t]{2}{*}{ Ibuprofen } & Lytechinus variegatus (sea urchin) & 326.6 & \multirow{4}{*}[76]{} \\
\hline & & Perna perna (bivalve) & $32.4-326.6$ & \\
\hline & \multirow{2}{*}{ Triclosan } & Lytechinus variegatus (sea urchin) & 20.18 & \\
\hline & & Perna perna (bivalve) & $2.01-20.18$ & \\
\hline
\end{tabular}

${ }^{\text {a }}$ HQ-Estimated hazard quotients.

Other multitarget analysis (78 PhaCs) was carried out in the Gulf of Cadiz (Spain), where the HQs showed no high environmental risk in both coastal and oceanic sampling areas, despite they were much greater than 1 for several compounds in the effluent of a near sewage treatment plant [68]. Thus, after dilution, only three compounds (ibuprofen, phenazone, salicylic acid) showed intermediate risk for daphnid, green algae and fish.

Seventeen PhaCs were evaluated in other place of the Spanish coast, this time in a Mediterranean marsh, detecting intermediate or high risk in green algae, daphnid or fish. Two quinolones, ciprofloxacin and ofloxacin, showed values of HQ in algae of 6.9 and 3.1, respectively. Other quinolone also results in a risk near to 1 (0.98) for algae [82].

In seawaters from north Portuguese coast, 7 PhaCs and 2 metabolites belonging to non-steroidal anti-inflammatory drugs and analgesics therapeutic classes were studied. The highest HQs were obtained for fish showing a high risk for diclofenac in two of the 
sampling points, while green algae and daphnids never exceeded the threshold value of 1. For daphnids and algae, the highest HQs (corresponding for intermediate risk) were obtained for acetaminophen and for ketoprofen, ibuprofen and naproxen, respectively [69].

Other concern family of emerging compounds is hormones. The HQ of estrone, 17$\beta$-estradiol, estriol and 17- $\alpha$-ethynylestradiol were evaluated in Biscayne Bay in Florida (USA), resulting in an unexpected high risk probably related with surface runoff and groundwater flow in coastal areas not served by municipal wastewater collection [55]. Despite estriol showed the highest environmental concentrations, the HQs calculated for estrone, 17- $\beta$-estradiol and 17- $\alpha$-ethynylestradiol were higher, as much as 651 for $17-\alpha-$ ethynylestradiol. The sum of quotients was also calculated; of the twenty-nine sampling sites, only one site had a $\Sigma \mathrm{HQ}$ below 1.

The studies related with the risk assessment of PCPs in seafront zones are even more scarce. The risk of 11 UV filters and 10 UV stabilizers were studied in Port Philip Bay in Australia, where only two chemicals, octocrylene (OC) and 2-ethylhexyl-4-methoxycinnamate (EHMC) had an HQ above 1. However, the authors also claim that the toxic effects of mixtures can occur at much lower concentrations than observed for individual chemicals, so compounds with the same mode of action may exert an additive toxicity effect [83].

HQs were also calculated for six UV stabilizers (UV-P, UV-326, UV-327, UV-328, UV329 and UV-360) regarding the concentrations found in seawater from 3 different points of the coastal of Gran Canaria island (Spain). In this case, only the measured concentrations for one compound, the UV-327, supposed an intermediate risk for two locations and for green algae and daphnid [84].

The presence of other three UV filters were revealed as a risk in a study of 100 priority and emerging pollutants carried out in the Capbreton Canyon, situated in the Bay of Biscay in NE Atlantic at $250 \mathrm{~m}$ from the coastline. Among the PCPs, only 3-(4-methylbenzylidene)camphor (4-MBC), EHMC and OC showed intermediate or high risk, with a maximum of 39.72 calculated for EHMC [85].

Several papers have also assessed the risk of emerging compounds using data from ecotoxicological studies in other species. Pusceddu et al. (2018) studied the chronic effects of a PhaC (ibuprofen) and a PCP (triclosan) through the embryo-larval development bioassay for the species Lytechinus variegatus (sea urchin) and Perna perna (bivalve). They were subjected to spiked sediments following two different exposure approaches, the sedimentwater and the sediment elutriate. HQ values were estimated taking into consideration the concentrations found in sediments of Santos Bay in Brazil, obtaining values well above 1, meaning high environmental risk [76].

In a study of 23 PhaCs near the diffusers of the Guaruja submarine outfall in São Paulo (Brazil), diclofenac was found to have a risk quotient value of 0.11 for the fish Danio rerio [80]. Since the authors state that diclofenac is a biologically active compound with a low biodegradation rate but with rapid photo transformation into new by-products, it is essential to control the levels of both the original compounds and their metabolites.

Other authors have also carried out embryotoxicity test and then estimated HQ values using environmental concentrations found in the literature. For example, the effect of gemfibrozil, propranolol and $17 \alpha$-ethinylestradiol were studied in seabream larvae (Sparus aurata), mussels (Mytilus galloprovincialis) and sea urchins (Paracentrotus lividus), obtaining median HQs values higher than 1 (high environmental risk) [86]. These results indicate that even compounds normally low concentrated in the marine environment might pose a hazard to the early life stages of some species.

More examples of $\mathrm{HQ}$ values are available in the literature, but using measured concentrations in treated sewage samples and receiving river waters [73,87,88]. However, despite these waters are the main source of pollution in the seafront zones, more studies are needed to assess the real risk for the environment.

$\mathrm{HQ}>1$ was calculated for $30 \mathrm{ECs}$ in Greek secondary treated wastewaters. In all studied rivers, triclosan presented $\mathrm{HQ}>1$ in algae, whereas decamethylcyclopentasilane in Daphnia magna, caffeine in algae and nonylphenol in fish showed HQ $>1$ in rivers 
with dilution factors equal or lower to 1910, 913 and 824, respectively [73]. Even though fortunately the dispersion and dilution of the pollutants decreases their potential risk, these quotients demonstrate that continuous entry of emerging pollutants in the environment must be urgently monitored and regulated, despite the dispersion that they undergo in the ocean. For calculating the risk quoting based on WWTP effluents, some authors employed a factor of 10 in order to include the dilution effects of the effluent waters around the waste water pipe outlets [89].

It is also need to include metabolites in the risk assessments, since there are already studies that pointed that their PEC or toxicity are higher than that of their parents, which resulted in greater HQs [51].

\section{Analytical Platforms for Detection and Quantification ECs}

The development of simple, fast, sensitive, selective and low-cost analytical platforms is of the utmost interest due to the complexity of seafront zones and aquatic environments surveillance monitoring of ECs, namely PhaCs and PCPs [74]. The analytical procedure for the detection and quantification of ECs in environmental samples is analogous to that for a diversity of organic contaminants and require a suitable pre-treatment step (e.g., extraction, purification) followed by an analysis using diverse separation and detection techniques. The selection of the most suitable analytical platform depends of the physicochemical properties of the target analytes and the sensitivity. As can be observed in the Tables 4 and 5, the most common extraction procedure and analytical platform used for the assessment of ECs in environmental samples is solid phase extraction (SPE) followed by liquid chromatography (LC) combined with mass spectrometry (MS). In the next sections will be discussed the different microextraction techniques and analytical platforms used in the extraction of ECs from environmental samples.

\subsection{Extraction Techniques}

\subsubsection{Extraction from Coastal Liquid Samples}

Samples from marine environments are complex matrices, which must be treated before analysis in order to minimize the presence of interferences that could affect the determination step. Furthermore, PhaCs and PCPs are usually presented in coastal environment samples at trace concentrations, which means that it is absolutely necessary to perform preconcentration techniques to obtain extracts at measurable and confident concentrations.

In this regard, different preconcentration and extraction techniques are used considering the physicochemical properties of the studied matrices. As can be seen in Table 4 for liquid samples, solid phase extraction (SPE) is the most used extraction technique. SPE has been established as extraction routine not only for marine waters, but also for other many types of environmental liquid samples as wastewaters, river or lake waters or even, groundwater $[90,91]$. Usually, PhaCs are analysed using multiresidue methodologies which could be performed for more than 50 PhaCs in a single procedure $[68,81,92,93]$. Considering the variety of physicochemical properties of PhaCs, which present very different molecular structures, solubilities, polarities and acidity constants, it is necessary to develop extraction procedures, which permit to extract as much compounds as possible. For this reason, the selection of an appropriate sorbent is a key factor in the development of extraction procedures. Silica $\mathrm{C}_{18}$ sorbents have reported good extraction yields for some PhaCs such as non-steroidal anti-inflammatory drugs (NSAIDs) [94]. Nevertheless, when a pharmaceutical multiresidue methodology is proposed, the best extraction efficiencies are usually obtained with polymeric sorbents with a hydrophobic-hydrophilic balance such as Oasis HLB cartridges. In this regard, in Table 4 it can be observed that most of the studies use this type of sorbent and the differences between studies are in the weight of polymer used. The weights of Oasis HLB are between $60 \mathrm{mg}$ in small SPE cartridges (with a volume of 3 o $6 \mathrm{~mL}$ ) and $1 \mathrm{~g}$, used as extraction polymer in the study of Munaron et al. (2012). In this study, the authors did not use the Oasis polymer in a SPE procedure but used it as extraction sorbent in a polar organic chemical integrative sampler (POCIS) device [95]. 
Other authors have substituted Oasis cartridges by similar sorbents based on polystyrenedivinylbenzene resins or similar polymers which present strong retention of neutral, acidic or basic compounds $[69,80,96-98]$.

Table 4. Extraction methodologies for (A) pharmaceuticals (PhaCs) and (B) personal care products (PCPs) present in coastal liquid samples.

\begin{tabular}{|c|c|c|c|c|c|}
\hline Studied ECs & $\begin{array}{c}\text { Sample Type and } \\
\text { Location }\end{array}$ & $\begin{array}{l}\text { Extraction } \\
\text { Technique }\end{array}$ & Extraction Conditions & $\begin{array}{l}\text { Recoveries } \\
(\%)\end{array}$ & Reference \\
\hline \multicolumn{6}{|c|}{ (A) PhaCs } \\
\hline $\begin{array}{c}\text { Caffeine and } 8 \\
\text { steroid hormones }\end{array}$ & $\begin{array}{l}\text { Seawater from Key Largo } \\
\text { Harbor (Miami, USA) }\end{array}$ & $\operatorname{LLE}^{a}$ & $\begin{array}{c}\text { SA }^{\mathrm{k}}: 2 \mathrm{~L} \\
\mathrm{ES}^{1}: 3 \times 50 \mathrm{~mL} \mathrm{DCM}{ }^{\mathrm{m}}\end{array}$ & - & [99] \\
\hline Enrofloxacin & $\begin{array}{l}\text { Seawater from São Luís } \\
\text { (Brazil) }\end{array}$ & UA-DLLME $^{\mathrm{b}}$ & $\begin{array}{c}\text { SA: } 8 \mathrm{~mL} \\
\text { ES: chloroform } \\
\text { DS }^{n}: \mathrm{MeCN}^{\mathrm{o}}\end{array}$ & 70 & [100] \\
\hline 9 PhaCs & $\begin{array}{l}\text { Waters from Yangtze } \\
\text { Estuary and its coastal } \\
\text { area (China) }\end{array}$ & $\mathrm{SPE}^{\mathrm{c}}$ & $\begin{array}{c}\text { SA: } 1 \mathrm{~L} \text { water, } 2 \mathrm{~kg} \text { sediments } \\
\text { SPE cartridge: Oasis HLB }(200 \mathrm{mg}, 6 \mathrm{~mL}) \\
\text { ES: } \mathrm{MeOH}^{\mathrm{P}}\end{array}$ & $51-103$ & [101] \\
\hline $\begin{array}{l}33 \text { PhaCs, cocaine } \\
\text { and its } \\
\text { main metabolite }\end{array}$ & $\begin{array}{l}\text { Seawater from Santos Bay } \\
\text { (São Paulo, Brazil) }\end{array}$ & SPE & $\begin{array}{c}\text { SA: } 1 \mathrm{~L} \\
\text { SPE cartridge: Chromabond HR-X } \\
(200 \mathrm{mg}, 3 \mathrm{~mL}) \\
\text { ES: } 5 \mathrm{~mL} \text { Acet } \mathrm{q}, 2 \times 5 \mathrm{~mL} \mathrm{MeOH}\end{array}$ & - & [96] \\
\hline 68 PhaCs & $\begin{array}{l}\text { Waters from } \\
\text { Mediterranean coastal } \\
\text { lagoon (Mar Menor, } \\
\text { South East of Spain) }\end{array}$ & SPE & $\begin{array}{c}\text { SA: } 250 \mathrm{~mL} \\
\text { SPE cartridge: Oasis HLB }(60 \mathrm{mg}, 3 \mathrm{~mL}) \\
\text { ES: } 6 \mathrm{~mL} \mathrm{MeOH}\end{array}$ & $31-200$ & [102] \\
\hline 80 PhaCs & $\begin{array}{l}\text { Waters from southern } \\
\text { coast of Viti Levu (Fiji) }\end{array}$ & SPE & $\begin{array}{c}\text { SA: } 500 \mathrm{~mL} \\
\text { SPE cartridge: Oasis HLB (200 mg, } 3 \mathrm{~mL}) \\
\text { ES: } 5 \mathrm{~mL} \text { MeOH, } 3 \mathrm{~mL} \mathrm{EtAc}^{\text {r }}\end{array}$ & - & [92] \\
\hline $\begin{array}{l}4 \text { antibiotics and } \\
1 \text { analgesic }\end{array}$ & $\begin{array}{l}\text { Waters from shrimp } \\
\text { producing areas located } \\
\text { on the north coast of } \\
\text { Central Java (Indonesia) }\end{array}$ & SPE & $\begin{array}{c}\text { SA: } 800 \mathrm{~mL} \\
\text { SPE cartridge: Oasis HLB }(200 \mathrm{mg}, 6 \mathrm{~mL}) \\
\text { ES: } 5 \mathrm{~mL} \mathrm{H} \mathrm{H}_{2} \mathrm{O}: \operatorname{MeCN}(10: 90, v / v)\end{array}$ & $83-96$ & [103] \\
\hline 77 antibiotics & $\begin{array}{l}\text { Waters from coastal area } \\
\text { of Hangzhou Bay (China) }\end{array}$ & SPE & $\begin{array}{c}\text { SA: } 0.5-2 \mathrm{~L} \\
\text { SPE cartridge: Oasis HLB }(200 \mathrm{mg}, 6 \mathrm{~mL}) \\
\text { ES: } 10 \mathrm{~mL} \mathrm{MeOH}\end{array}$ & 69-115 & [93] \\
\hline 77 Antibiotics & $\begin{array}{l}\text { Waters from Hangzhou } \\
\text { Bay, Xiangshan Bay and } \\
\text { Taizhou Bay (China) }\end{array}$ & SPE & $\begin{array}{c}\text { SA: } 1 \mathrm{~L} \\
\text { SPE cartridge: Oasis HLB }(200 \mathrm{mg}, 6 \mathrm{~mL}) \\
\text { ES: } 10 \mathrm{~mL} \text { MeOH }\end{array}$ & 69-115 & [81] \\
\hline $\begin{array}{l}23 \text { PhaCs (including } \\
\text { illicit drugs) }\end{array}$ & $\begin{array}{l}\text { Waters from Guarujá } \\
\text { coast (São Paulo, Brazil) }\end{array}$ & SPE & $\begin{array}{c}\text { SA: } 1 \mathrm{~L} \\
\text { SPE cartridge: Chromabond HR-X } \\
(200 \mathrm{mg}, 3 \mathrm{~mL}) \\
\text { ES: } 2 \times 5 \mathrm{~mL} \mathrm{MeOH}, 5 \mathrm{~mL} \text { Acet }\end{array}$ & - & [80] \\
\hline 5 PhaCs & $\begin{array}{l}\text { Marine surface waters } \\
\text { from the west coast of } \\
\text { Ireland }\end{array}$ & SPE & $\begin{array}{c}\text { SA: } 500 \mathrm{~mL} \\
\text { SPE cartridge: Strata-X cartridges } \\
(200 \mathrm{mg}, 6 \mathrm{~mL}) \\
\text { ES: EtAc : Acet }(50: 50, v / v)\end{array}$ & $56-110$ & [97] \\
\hline 32 PhaCs & $\begin{array}{l}\text { Coastal waters from } \\
\text { Costa Rica }\end{array}$ & SPE & $\begin{array}{c}\text { SA: } 350 \mathrm{~mL} \\
\text { SPE cartridge: Strata-X }(200 \mathrm{mg}, 6 \mathrm{~mL}) \\
\text { ES: } 2 \times 3 \mathrm{~mL} \mathrm{MeOH}\end{array}$ & $>70$ & [98] \\
\hline $\begin{array}{l}7 \text { NSAIDs-analgesic } \\
\text { and } 2 \text { metabolites }\end{array}$ & $\begin{array}{l}\text { Waters from North } \\
\text { Portuguese coast } \\
\text { (beaches and cities) }\end{array}$ & SPE & $\begin{array}{c}\text { SA: } 500 \mathrm{~mL} \\
\text { SPE cartridge: Strata-X }(200 \mathrm{mg}, 3 \mathrm{~mL}) \\
\text { ES: } 2 \times 5 \mathrm{~mL} \text { MeOH }\end{array}$ & - & [69] \\
\hline 30 PhaCs & $\begin{array}{l}\text { Waters from Singapore } \\
\text { coast }\end{array}$ & SPE & $\begin{array}{c}\text { SA: } 1 \mathrm{~L} \\
\text { SPE cartridge: HLB }(60 \mathrm{mg}, 3 \mathrm{~mL}) \\
\text { ES: } 12 \mathrm{~mL} \text { MeOH, } 6 \mathrm{~mL} \mathrm{MeOH} / \text { Acet } \\
(1: 1, \mathrm{v} / \mathrm{v})\end{array}$ & $70-130$ & [104] \\
\hline 10 PhaCs & $\begin{array}{l}\text { Surface Water around } \\
\text { Liberty Bay, Puget Sound, } \\
\text { (Washington, USA) }\end{array}$ & SPE & $\begin{array}{c}\text { SA: } 1 \mathrm{~L} \\
\text { SPE cartridge: Oasis HLB }(200 \mathrm{mg}, 6 \mathrm{~mL}) \\
\text { ES: } 5 \mathrm{~mL} \text { MeOH : } \text { MTBE }^{\mathrm{s}}(10: 90, v / v)\end{array}$ & - & [105] \\
\hline
\end{tabular}


Table 4. Cont.

\begin{tabular}{|c|c|c|c|c|c|}
\hline Studied ECs & $\begin{array}{l}\text { Sample Type and } \\
\text { Location }\end{array}$ & $\begin{array}{l}\text { Extraction } \\
\text { Technique }\end{array}$ & Extraction Conditions & $\begin{array}{l}\text { Recoveries } \\
(\%)\end{array}$ & Reference \\
\hline \multicolumn{6}{|c|}{$\begin{array}{ll} & \text { (A) PhaCs }\end{array}$} \\
\hline $\begin{array}{l}4 \text { Steroid } \\
\text { hormones }\end{array}$ & $\begin{array}{c}\text { Seawater samples from } \\
24 \text { locations across Erebus } \\
\text { Bay (Antartica) }\end{array}$ & SPE & $\begin{array}{c}\text { SA: } 4 \mathrm{~L} \\
\text { SPE cartridge: Oasis HLB }(1 \mathrm{~g}, 20 \mathrm{~mL}) \\
\text { ES: } 6 \times 5 \text { mL DCM:MeOH }(95: 5)\end{array}$ & $95-143$ & [106] \\
\hline 78 PhaCs & $\begin{array}{l}\text { Coastal waters from the } \\
\text { Cadiz Bay (Spain) }\end{array}$ & SPE & $\begin{array}{l}\text { SA: } 200-500 \mathrm{~mL} \\
\text { SPE cartridge: Oasis HLB }(200 \mathrm{mg}, 6 \mathrm{~mL}) \\
\text { ES: } 10 \mathrm{~mL} \mathrm{MeOH}\end{array}$ & $17-117$ & [68] \\
\hline 21 PhaCs & $\begin{array}{l}\text { Seawaters from French } \\
\text { Mediterranean coast }\end{array}$ & SPE & $\begin{array}{c}\text { SA: } 1 \mathrm{~L} \\
\text { SPE cartridge: Oasis HLB }(200 \mathrm{mg}, 6 \mathrm{~mL}) \\
\text { ES: } 10 \mathrm{~mL} \text { MeOH, } 10 \mathrm{~mL} \mathrm{MeOH}: \mathrm{DCM} \\
(50: 50, v / v), 10 \mathrm{~mL} \mathrm{DCM}\end{array}$ & 75-105 & [95] \\
\hline 17 PhaCs & $\begin{array}{l}\text { Waters from } \\
\text { Mediterranean coastal } \\
\text { wetland (Pego-Oliva } \\
\text { marsh, Spain) }\end{array}$ & SPE & $\begin{array}{c}\text { SA: } 250 \mathrm{~mL} \\
\text { SPE cartridge: Oasis HLB }(200 \mathrm{mg}, 6 \mathrm{~mL}) \\
\text { ES: } 6 \mathrm{~mL} \mathrm{MeOH}\end{array}$ & $>70$ & [82] \\
\hline 43 PhaCs & $\begin{array}{l}\text { Waters from shorelines of } \\
\text { German), Italy, Greece, } \\
\text { Turkey, USA, Israel } \\
\text { and Spain }\end{array}$ & SPE & $\begin{array}{c}\text { SA: } 500 \mathrm{~mL} \\
\text { SPE cartridge: Oasis HLB }(500 \mathrm{mg}, 6 \mathrm{~mL}) \\
\text { ES: } 2 \times 2 \mathrm{~mL} \mathrm{MeOH}, 2 \times 2 \mathrm{~mL} \mathrm{EtAc}\end{array}$ & $80-110$ & [107] \\
\hline 8 PhaCs & $\begin{array}{l}\text { Waters from the Pearl } \\
\text { River Estuary (China) }\end{array}$ & $\underset{\mathrm{d}}{\text { Automated SPME }}$ & $\begin{array}{c}\text { SA: } 10 \mathrm{~mL} \\
\text { SPME fiber: PDMS }{ }^{\mathrm{t}} \\
\text { EC }^{\mathrm{u}}: 80^{\circ} \mathrm{C}, 60 \mathrm{~min}, 500 \mathrm{rpm}\end{array}$ & $85-110$ & [108] \\
\hline 7 PhaCs & $\begin{array}{l}\text { Waters from South China } \\
\text { Sea (China) }\end{array}$ & SPME & $\begin{array}{c}\text { SA: } 8 \mathrm{~mL} \\
\text { SPME fiber: PS/PEGDA }{ }^{\mathrm{v}} \\
\text { EC: } 80^{\circ} \mathrm{C}, 12 \mathrm{~h}, 600 \mathrm{rpm}\end{array}$ & $81-105$ & [109] \\
\hline 22 PhaCs & $\begin{array}{l}\text { Water samples from the } \\
\text { estuary of Bilbao (Spain) }\end{array}$ & $\begin{array}{l}\text { Polyethersulfone } \\
\text { microextraction }\end{array}$ & $\begin{array}{l}\text { SA: } 120 \mathrm{~mL} \\
\text { ES: } 1 \mathrm{~mL} \mathrm{MeOH}\end{array}$ & $75-105 \%$ & [110] \\
\hline \multicolumn{6}{|c|}{ (B) PCPs } \\
\hline Triclosan & $\begin{array}{l}\text { Seawater from Key Largo } \\
\text { Harbor (Miami, USA) }\end{array}$ & LLE & $\begin{array}{c}\text { SA: } 2 \mathrm{~L} \\
\text { ES: } 3 \times 50 \mathrm{~mL} \mathrm{DCM}\end{array}$ & - & [99] \\
\hline $\begin{array}{l}4 \text { Benzophenone } \\
\text { UV filters }\end{array}$ & $\begin{array}{l}\text { Surface water from } \\
\text { different beaches located } \\
\text { in the Mediterranean } \\
\text { coast (Spain) }\end{array}$ & DLLME $^{\mathrm{e}}$ & $\begin{array}{l}\text { SA: } 5 \mathrm{~mL} \\
\text { ES: chloroform } \\
\text { DS: Acet }\end{array}$ & $65-222$ & [111] \\
\hline 8 UV filters & $\begin{array}{l}\text { Seawater samples from } \\
\text { different beaches in } \\
\text { Western Mediterranean } \\
\text { Sea (Spain) }\end{array}$ & DLLME & $\begin{array}{l}\text { SA: } 5 \mathrm{~mL} \\
\text { ES: chloroform } \\
\text { DS: Acet }\end{array}$ & $87-117$ & [112] \\
\hline $\begin{array}{l}6 \text { UV filters and } \\
13 \text { musks }\end{array}$ & $\begin{array}{l}\text { Seawater from Angeiras } \\
\text { Sul and Carneiro beach } \\
\text { (Portugal) }\end{array}$ & DLLME & $\begin{array}{c}\text { SA: } 6 \mathrm{~mL} \\
\text { ES: 1,1,2-trichloroethane } \\
\text { DS: 2-propanol }\end{array}$ & $80-120$ & [113] \\
\hline $\begin{array}{l}4 \text { Benzophenone } \\
\text { UV filters }\end{array}$ & $\begin{array}{l}\text { Surface water from } \\
\text { different beaches located } \\
\text { in the Mediterranean } \\
\text { coast (Spain) }\end{array}$ & DLLME & $\begin{array}{l}\text { SA: } 5 \mathrm{~mL} \\
\text { ES: chloroform } \\
\text { DS: Acet }\end{array}$ & $65-222$ & [111] \\
\hline 3 UV filters & $\begin{array}{l}\text { Seawater from Kenting } \\
\text { National Park (Taiwan) }\end{array}$ & LPME $^{\mathrm{f}}$ & $\begin{array}{c}\text { SA: } 500 \mathrm{~mL} \\
\text { ES: } 1 \text {-octanol : isooctane }(2: 8, v / v)\end{array}$ & $67-115$ & [114] \\
\hline $\begin{array}{c}\text { Triclosan, } \\
\text { salicylic acid }\end{array}$ & $\begin{array}{l}\text { Coastal waters from } \\
\text { Costa Rica }\end{array}$ & SPE & $\begin{array}{c}\text { SA: } 350 \mathrm{~mL} \\
\text { SPE cartridge: Strata-X }(200 \mathrm{mg}, 6 \mathrm{~mL}) \\
\text { ES: } 2 \times 3 \mathrm{~mL} \mathrm{MeOH}\end{array}$ & $>70$ & [98] \\
\hline Triclosan & $\begin{array}{l}\text { Waters from Singapore } \\
\text { coast }\end{array}$ & SPE & $\begin{array}{c}\text { SA: } 1 \mathrm{~L} \\
\text { SPE cartridge: HLB }(60 \mathrm{mg}, 3 \mathrm{~mL}) \\
\text { ES: } 12 \mathrm{~mL} \text { MeOH, } 6 \mathrm{~mL} \mathrm{MeOH}: \text { Acet } \\
(1: 1, v / v)\end{array}$ & $70-130$ & [104] \\
\hline
\end{tabular}


Table 4. Cont.

\begin{tabular}{|c|c|c|c|c|c|}
\hline Studied ECs & Sample Type and Location & $\begin{array}{l}\text { Extraction } \\
\text { Technique }\end{array}$ & Extraction Conditions & $\begin{array}{c}\text { Recoveries } \\
(\%)\end{array}$ & Reference \\
\hline \multicolumn{6}{|c|}{ (B) PCPs } \\
\hline $\begin{array}{l}\text { Oxybenzone and } \\
\text { triclosan }\end{array}$ & $\begin{array}{l}\text { Surface Water around } \\
\text { Liberty Bay, Puget Sound, } \\
\text { (Washington, USA) }\end{array}$ & SPE & $\begin{array}{c}\text { SA: 1 L } \\
\text { SPE cartridge: Oasis HLB } \\
(200 \mathrm{mg}, 6 \mathrm{~mL}) \\
\text { ES: } 5 \mathrm{~mL} \mathrm{MeOH} \mathrm{:} \mathrm{MTBE}(10: 90, v / v)\end{array}$ & - & [105] \\
\hline $\begin{array}{l}\text { Triclosan and } \\
4 \text { parabens }\end{array}$ & $\begin{array}{c}\text { Seawater samples from } \\
24 \text { locations across Erebus } \\
\text { Bay (Antartica) }\end{array}$ & SPE & $\begin{array}{c}\text { SA: } 4 \mathrm{~L} \\
\text { SPE cartridge: Oasis HLB }(1 \mathrm{~g}, 20 \mathrm{~mL}) \\
\text { ES: } 6 \times 5 \text { mL DCM:MeOH }(95: 5)\end{array}$ & $82-124$ & [106] \\
\hline $\begin{array}{l}7 \text { Benzotriazole } \\
\text { UV stabilizers }\end{array}$ & $\begin{array}{l}\text { Seawater from beaches } \\
\text { around the coast of Gran } \\
\text { Canaria (Spain) }\end{array}$ & On-line SPE & $\begin{array}{c}\text { SA: } 1 \\
\text { LSPE cartridge: Oasis HLB } \\
(200 \mathrm{mg}, 6 \mathrm{~mL}) \text { direct connect HP } \\
\text { Column }(2.1 \times 30 \mathrm{~mm}, 20 \mu \mathrm{m}) \\
\text { ES: } 2 \mathrm{~mL} \mathrm{MeOH}\end{array}$ & $60-89$ & [115] \\
\hline 2 Preservatives & $\begin{array}{l}\text { Water samples from the } \\
\text { estuary of Bilbao (Spain) }\end{array}$ & $\begin{array}{l}\text { Polyethersulfone } \\
\text { microextraction }\end{array}$ & $\begin{array}{c}\text { SA: } 120 \mathrm{~mL} \\
\text { ES: } 1 \mathrm{~mL} \mathrm{MeOH}\end{array}$ & 75-105 & [110] \\
\hline $\begin{array}{l}4 \text { Benzophenone } \\
\text { UV filters }\end{array}$ & $\begin{array}{l}\text { Seawater from Costa de } \\
\text { Caparica (Portugal) }\end{array}$ & $\mathrm{BA} \mu \mathrm{E} g$ & $\begin{array}{c}\text { SA: } 25 \mathrm{~mL} \\
\text { EC: } 4-16 \mathrm{~h}, 1000 \mathrm{rpm} \\
\text { ES: } 1.5 \mathrm{~mL} \mathrm{MeCN} / \mathrm{MeOH}(1: 1, v / v)\end{array}$ & $76-103$ & [116] \\
\hline 7 UV stabilizers & $\begin{array}{l}\text { Seawater from beaches } \\
\text { around the coast of Gran } \\
\text { Canaria (Spain) }\end{array}$ & SBSE $^{\mathrm{h}}$ & $\begin{array}{c}\text { SA: } 25 \mathrm{~mL} \\
\text { Polymer: PDMS w } \\
\text { ES: ??? }\end{array}$ & $18-92$ & [117] \\
\hline 10 UV filters & $\begin{array}{l}\text { Seawater from a } \\
\text { bathing area }\end{array}$ & USAEME $^{\mathrm{i}}$ & $\begin{array}{c}\text { SA: } 10 \mathrm{~mL} \\
\text { ES: chloroform } \\
\text { EC: } 5 \mathrm{~min}, 25^{\circ} \mathrm{C}, 35 \mathrm{kHz}\end{array}$ & 73-105 & [118] \\
\hline $\begin{array}{l}7 \text { Benzotriazole } \\
\text { UV stabilizers }\end{array}$ & $\begin{array}{l}\text { Seawater from beaches in } \\
\text { the southwest of Gran } \\
\text { Canaria (Spain) }\end{array}$ & FPSE $^{j}$ & $\begin{array}{c}\text { SA: } 25 \mathrm{~mL} \\
\text { Coated FPSE: PDMDPS } \\
\text { EC: } 2 \mathrm{~mL} \mathrm{MeCN}: \text { MeOH }(50: 50, v / v), \\
1000 \mathrm{rpm}\end{array}$ & $9-51$ & [119] \\
\hline
\end{tabular}

${ }^{\mathrm{a}}$ Liquid-liquid extraction; ${ }^{\mathrm{b}}$ Ultrasound-assisted dispersive liquid-liquid microextraction; ${ }^{\mathrm{c}}$ Solid phase extraction; ${ }^{\mathrm{d}}$ Solid phase microextraction; ${ }^{\mathrm{e}}$ Dispersive liquid-liquid microextraction; ${ }^{\mathrm{f}}$ Liquid-phase microextraction; ${ }^{\mathrm{g}}$ Bar adsorptive micro-extraction; ${ }^{\mathrm{h}}$ Stir-bar sorptive extraction; ${ }^{\mathrm{i}}$ Ultrasound-assisted emulsification microextraction; ${ }^{\mathrm{j}}$ Fabric phase sorptive extraction; ${ }^{\mathrm{k}}$ Sample amount; ${ }^{1}$ Extraction solvent; ${ }^{\mathrm{m}}$ Dichloromethane; ${ }^{\mathrm{n}}$ Dispersive solvent; ${ }^{\mathrm{o}}$ Acetonitrile; ${ }^{\mathrm{P}}$ Methanol; ${ }^{\mathrm{q}}$ Acetone; ${ }^{\mathrm{r}}$ Ethyl acetate; ${ }^{\mathrm{s}}$ Methyl tert-butyl ether; ${ }^{\mathrm{t}}$ Polydimethylsiloxane; ${ }^{\mathrm{u}}$ Extraction conditions; ${ }^{\mathrm{v}}$ Styrene/ poly(ethylene glycol) diacrylate; ${ }^{\mathrm{w}}$ Poly(dimethyldiphenylsiloxane).

Regarding PCPs, many authors have used polymeric sorbents such as Oasis HLB or Strata- $X$ due to these compounds are usually determined with pharmaceuticals or other emerging pollutants $[98,104-106]$. Oasis HLB sorbent have been used also in an on-line SPE procedure developed for the extraction of 7 benzotriazole UV stabilizers. In this study, the polymer is contained in special cartridges, similar to high performance liquid chromatography (HPLC) columns where the extraction of target analytes is performed at high pressures [115]. For both PhaCs and PCPs, sample volumes are very varied and are related in most cases with the expected concentrations of these emerging pollutants. The volumes of the consulted bibliography varied from $200 \mathrm{~mL}$ up to $4 \mathrm{~L}$ of samples used, for example in the determination of PCPs in seawater from Antarctica [106].

Some studies have evaluated the efficiency of different extraction methods for PCPs in coastal waters. Singh et al. (2010) used liquid-liquid extraction (LLE) with methylene chloride (DCM) for the extraction of caffeine, triclosan and 8 steroid hormones from seawater [99]. Nevertheless, in recent years, the alternatives to SPE have been focused in the microextraction techniques and for this, many different microextraction techniques have been developed for the determination of PCPs. Solid phase microextraction (SPME) is one of the most studied miniaturized extraction techniques and has been satisfactorily applied to the extraction of these compounds in marine samples. Some authors have reported extraction procedures using polydimethylsiloxane or divinylbenzene fibers $[108,120]$ while others have prepared their own fibers as the case of Wang et al. (2020) that used a styrene and poly(ethyleneglycol) diacrilate fiber [109]. Recently, other authors have reported the use of different microextraction techniques for PCPs in marine aqueous samples. 
Mijangos et al. (2018) optimized a polyethersulfone microextraction for $22 \mathrm{PhaCs}$ and 2 preservatives in estuarine samples [110] while Dias et al. (2021) developed a extraction method for antibiotic enrofloxacin using dispersive liquid-liquid microextraction assisted with sonication (UA-DLLME) [100], both with satisfactory results (recoveries over 70\%). Some of them are based on liquid extraction such as dispersive liquid-liquid microextraction (DLLME) [111-113], liquid-phase microextraction (LPME) [114] or ultrasound assisted emulsification microextraction (USAEME) [118] while other microextraction techniques are based on the adsorption of the contaminants on a device that could be a bar such as stir-bar sorptive extraction (SBSE) or bar adsorptive microextraction $(\mathrm{BA} \mu \mathrm{E})[116,117]$, or a fabric device as using fabric phase sorptive extraction (FPSE) [119]. It is important to highlight that most of these microextraction techniques are based on equilibrium processes and for this reason the recoveries are not as high as using exhaustive extraction methodologies such as SPE. Another important difference between the use of SPE and microextraction techniques is the number of compounds extracted. Generally, microextraction technique are able to extract up to 10 compounds while SPE is often used in multiresidue approaches.

\subsubsection{Extraction from Coastal Solid Samples}

Extraction methods for solid samples are not as standardized as SPE for liquid samples. For marine samples, some authors have extracted PCPs by shaking with an organic solvent $[121,122]$. Nevertheless, most of the consulted studies use instrumental methodologies for the extraction of PCPs from marine sediments and sand such as ultrasound assisted extraction (UAE), pressurized solvent extraction (PSE), microwave assisted extraction (MAE) or recent developed extraction techniques such as quick, easy, cheap, effective, rugged and safe (QuEChERS) (Table 5).

Table 5. Extraction methodologies for PPCPs present in coastal solid samples.

\begin{tabular}{|c|c|c|c|c|c|}
\hline Studied ECs & Sample Type and Location & $\begin{array}{l}\text { Extraction } \\
\text { Technique }\end{array}$ & Extraction Conditions & $\begin{array}{c}\text { Recoveries } \\
(\%)\end{array}$ & Reference \\
\hline $\begin{array}{c}3 \text { PhaCs, } 3 \text { steroid } \\
\text { hormones, } \\
\text { oxybenzone, triclosan }\end{array}$ & $\begin{array}{l}\text { Sediments from southern } \\
\text { California Bight (USA) }\end{array}$ & Accel. shacking & SA: $2 \mathrm{~g}$ & $86-91$ & {$[122]$} \\
\hline Parabens & $\begin{array}{c}\text { Sediments from Sihwa lake } \\
\text { (Korea) and Tokyo Bay } \\
\text { (Japan) }\end{array}$ & $\begin{array}{l}\text { Shacking } \\
\text { Clean-up: SPE a }\end{array}$ & $\begin{array}{c}\text { SA }^{\text {h. }}: 100-500 \mathrm{mg} \\
\text { EC }^{\mathrm{i}}: 5 \mathrm{~mL} \text { MeOH: } \mathrm{H}_{2} \mathrm{O} \\
(5: 3 \mathrm{v} / \mathrm{v}), 60 \mathrm{minSPE} \text { cartridge: } \\
\text { Oasis MCX }(60 \mathrm{mg}, 3 \mathrm{~mL}) \\
\text { Clean-up ES } \mathrm{j}: 5 \mathrm{~mL} \mathrm{MeOH}{ }^{\mathrm{k}}\end{array}$ & 81-119 & {$[121]$} \\
\hline 77 antibiotics & $\begin{array}{c}\text { Sediments from Hangzhou } \\
\text { Bay, Xiangshan Bay and } \\
\text { Taizhou Bay (China) }\end{array}$ & $\begin{array}{c}\mathrm{UAE}^{\mathrm{b}}(\mathrm{x} 2) \\
\text { Clean-up: SPE }\end{array}$ & $\begin{array}{c}\text { SA: } 2 \mathrm{~g} \\
20 \mathrm{~mL} \mathrm{MeCN}^{1}: \text { EDTA } \\
\text { m-Mcllvaine Buffer }(1: 1, v / v) \\
\text { SPE cartridge: Oasis MCX } \\
(200 \mathrm{mg}, 6 \mathrm{~mL}) \\
\text { ES: } 10 \mathrm{~mL} \mathrm{MeOH}\end{array}$ & - & {$[81]$} \\
\hline 6 PhaCs and 2 musks & $\begin{array}{l}\text { Eulittoral and infralittoral } \\
\text { sediments from Todos os } \\
\text { Santos Bay (Brazil) }\end{array}$ & UAE (x2) & $\begin{array}{c}\text { SA: } 2 \mathrm{~g} \\
\text { ES: } 15 \mathrm{~mL} \mathrm{MeOH}, 20 \mathrm{~min}\end{array}$ & $>87$ & {$[123]$} \\
\hline 43 PhaCs & $\begin{array}{l}\text { Sediments from Capbreton } \\
\text { Canyon (South-Eastern Bay of } \\
\text { Biscay, NE Atlantic) }\end{array}$ & $\begin{array}{c}\text { UAE } \\
\text { Clean-up: SPE }\end{array}$ & $\begin{array}{c}\text { SA: } 0.2 \mathrm{~g} \\
\text { EC: } 1 \mathrm{~mL} \mathrm{MeOH}, 1 \mathrm{~mL} \\
\mathrm{NH}_{4} \mathrm{Cl}^{\mathrm{n}}, 0.2 \mathrm{~mL} \mathrm{Na}_{2} \mathrm{EDTA}^{\circ} \\
20 \mathrm{~min} \\
\text { SPE cartridge: Oasis HLB } \\
(60 \mathrm{mg}, 3 \mathrm{~mL}) \\
\text { ES: } 1 \mathrm{~mL} \mathrm{H}_{2} \mathrm{O}: \mathrm{MeOH} \\
(95: 5, v / v)\end{array}$ & $22-134$ & {$[85]$} \\
\hline $\begin{array}{l}84 \text { PhaCs, triclosan } \\
\text { and triclocarban }\end{array}$ & $\begin{array}{c}\text { Sediments from nearshore } \\
\text { sites in San Francisco Bay, } \\
\text { CA, USA }\end{array}$ & $\begin{array}{c}\text { UAE } \\
\text { Clean-up: SPE }\end{array}$ & $\begin{array}{c}\text { SA: } 1 \mathrm{~g} \\
\text { EC: aqueous phosphate } \\
\text { buffered (pH 2), MeCN p } \\
\text { SPE cartridge: Oasis HLB } \\
\text { (200 mg, } 6 \mathrm{~mL}) \\
\text { ES: MeCN }\end{array}$ & $21-231$ & {$[124]$} \\
\hline
\end{tabular}


Table 5. Cont.

\begin{tabular}{|c|c|c|c|c|c|}
\hline Studied ECs & Sample Type and Location & $\begin{array}{l}\text { Extraction } \\
\text { Technique }\end{array}$ & Extraction Conditions & $\begin{array}{c}\text { Recoveries } \\
(\%)\end{array}$ & Reference \\
\hline $\begin{array}{l}31 \text { PhaCs, triclosan } \\
\text { and triclocarban }\end{array}$ & $\begin{array}{c}\text { Sediments from Pearl River } \\
\text { Delta (China) }\end{array}$ & $\begin{array}{c}\operatorname{UAE}(x 2) \\
\text { Clean-up: SPE }\end{array}$ & $\begin{array}{c}\text { SA: } 2 \mathrm{~g} \\
\text { EC: } 5 \mathrm{~mL} \text { citrate buffer (pH 3), } \\
5 \mathrm{~mL} \text { MeCN, } 20 \mathrm{~min}, 25^{\circ} \mathrm{C} \\
\text { SPE cartridge: Oasis HLB } \\
(200 \mathrm{mg}, 6 \mathrm{~mL}) \\
\text { ES: } 10 \mathrm{~mL} \mathrm{MeOH}\end{array}$ & $43-127$ & [125] \\
\hline 119 PPCPs & $\begin{array}{c}\text { Sediments from Puget Sound } \\
\text { and Bellingham Bay, } \\
\text { Washington (USA) }\end{array}$ & $\begin{array}{c}\text { UAE }(x 2) \\
\text { Clean-up: SPE }\end{array}$ & $\begin{array}{c}\text { SA: } 1 \mathrm{~g} \\
\text { EC: } 20 \mathrm{~mL} \text { of } \mathrm{MeCN} \\
\text { SPE cartridge: HLB } \\
\text { ES: MeCN }\end{array}$ & - & [126] \\
\hline $\begin{array}{l}15 \text { PhaCs and } \\
\text { triclosan }\end{array}$ & $\begin{array}{l}\text { Sediments from mangroves } \\
\text { around Singapore }\end{array}$ & UAE & $\begin{array}{c}\text { SA: } 2.5 \mathrm{gEC}: 20 \mathrm{~mL} \mathrm{MeCN}, \\
30 \mathrm{~min}, 25^{\circ} \mathrm{C}, 12,000 \mathrm{rpm}\end{array}$ & $47-132$ & [127] \\
\hline 9 PhaCs & $\begin{array}{c}\text { Sediments from Yangtze } \\
\text { Estuary and its coastal area } \\
\text { (China) }\end{array}$ & $\mathrm{ASE}^{\mathrm{c}}$ & $\begin{array}{c}\text { SA: } 2 \mathrm{~kg} \\
\mathrm{EC}: 3 \times 15 \mathrm{~mL} \mathrm{MeOH}, 100{ }^{\circ} \mathrm{C}, \\
15 \mathrm{~min}, 100 \text { bars }\end{array}$ & $43-88$ & [101] \\
\hline 17 PhaCs & $\begin{array}{c}\text { Sediments and solis from a } \\
\text { mediterranean coastal } \\
\text { wetland (Pego-Oliva } \\
\text { marsh, Spain) }\end{array}$ & PSE & $\begin{array}{c}\text { SA: } 3 \mathrm{~g} \\
\text { EC: } \mathrm{H}_{2} \mathrm{O}, 90{ }^{\circ} \mathrm{C}\end{array}$ & $>87$ & [82] \\
\hline 68 PhaCs & $\begin{array}{c}\text { Sediments from a } \\
\text { mediterranean coastal lagoon } \\
\text { (Mar Menor, South East } \\
\text { of Spain) }\end{array}$ & $\begin{array}{c}\text { PLE }^{\mathrm{d}} \\
\text { Clean-up: SPE }\end{array}$ & $\begin{array}{c}\text { SA: } 1 \mathrm{~g} \\
\text { EC: } 1 \mathrm{~mL} \mathrm{MeOH} \mathrm{:} \mathrm{H}_{2} \mathrm{O} \\
(1: 2, v / v), 100{ }^{\circ} \mathrm{C} \\
\text { SPE cartridge: Oasis HLB } \\
(200 \mathrm{mg}, 6 \mathrm{~mL}) \\
\text { ES: } 1 \mathrm{~mL} \mathrm{MeOH} \mathrm{:} \mathrm{H}_{2} \mathrm{O} \\
(25: 75, v / v)\end{array}$ & $31-240$ & {$[102]$} \\
\hline 64 PhaCs & $\begin{array}{c}\text { Sediments from Long Island } \\
\text { Sound (LIS) Estuary (New } \\
\text { York, USA) }\end{array}$ & $\begin{array}{c}\text { ASE } \\
\text { Clean-up: SPE }\end{array}$ & $\begin{array}{c}\text { SA: } 2 \mathrm{~g} \\
\text { EC: } \mathrm{MeOH}: \mathrm{H}_{2} \mathrm{O}(1: 2, v / v), \\
100{ }^{\circ} \mathrm{C}, 1500 \mathrm{psi} \\
\text { SPE cartridge: Oasis HLB } \\
(200 \mathrm{mg}, 6 \mathrm{~mL}) \\
\text { ES: } 8 \mathrm{~mL} \mathrm{MeOH}\end{array}$ & - & [128] \\
\hline 47 PhaCs & $\begin{array}{l}\text { Sediments from greater } \\
\text { Auckland region } \\
\text { (New Zealand) }\end{array}$ & $\begin{array}{c}\text { ASE } \\
\text { Clean-up: SPE }\end{array}$ & $\begin{array}{c}\text { SA: } 1 \mathrm{~g} \\
\text { EC: MeOH : } \mathrm{H}_{2} \mathrm{O}(1: 2, v / v) \\
100{ }^{\circ} \mathrm{C}, 1500 \mathrm{psi} \\
\text { SPE cartridge: Oasis HLB } \\
(500 \mathrm{mg}, 6 \mathrm{~mL}) \\
\text { ES: } 2 \times 4 \mathrm{~mL} \mathrm{MeOH}\end{array}$ & $11-222$ & {$[129]$} \\
\hline $\begin{array}{l}5 \text { fluoroquinolone } \\
\text { antibiotics }\end{array}$ & $\begin{array}{c}\text { Sediments from the } \\
\text { southwest coast of Gran } \\
\text { Canaria (Spain) }\end{array}$ & $\mathrm{MAE}^{\mathrm{e}}$ & $\begin{array}{c}\text { SA: } 2 \mathrm{~g} \\
\text { EC: micellar solution (HTAB) }\end{array}$ & $73-96$ & {$[130]$} \\
\hline $\begin{array}{l}7 \text { benzotriazole } \\
\text { UV stabilizers }\end{array}$ & $\begin{array}{l}\text { Sediments from three } \\
\text { touristic beaches of Gran } \\
\text { Canaria (Spain) }\end{array}$ & $\begin{array}{l}\text { MAE } \\
\text { Clean-up: On-line } \\
\text { SPE }\end{array}$ & $\begin{array}{c}\text { SA: } 1 \mathrm{~g} \\
\text { EC: } \mathrm{MeCN} \\
\text { SPE cartridge: Oasis HLB } \\
\text { Direct Connect HP Column } \\
(2.1 \mathrm{~mm} \times 30 \mathrm{~mm}, 20 \mu \mathrm{m}) \\
\text { ES: MeOH with } 0.1 \%, v / v, \\
\text { formic acid }\end{array}$ & $50-85$ & {$[131]$} \\
\hline $\begin{array}{l}6 \text { UV filters and } \\
9 \text { musks }\end{array}$ & $\begin{array}{c}\text { Sediments from Capbreton } \\
\text { Canyon (South-Eastern Bay of } \\
\text { Biscay, NE Atlantic) }\end{array}$ & QuEChERS $^{\mathrm{f}}$ & $\begin{array}{l}\text { SA: } 2 \mathrm{~g} \\
\text { EC: citrate buffer salt mixture, } \\
4 \mathrm{~mL} \mathrm{H}_{2} \mathrm{O}, 10 \mathrm{~mL} \text { EtAc } \mathrm{q}: \text { Tol } \\
{ }_{\mathrm{r}}(75: 25, v / v)\end{array}$ & $65-143$ & [85] \\
\hline $\begin{array}{l}11 \text { multiclass } \\
\text { ultraviolet (UV) } \\
\text { filters }\end{array}$ & $\begin{array}{l}\text { Sand from beaches from } \\
\text { Atlantic Ocean coast (Spain } \\
\text { and Portugal) }\end{array}$ & SPME g & $\begin{array}{c}\text { SA: } 1 \mathrm{~g} \\
\text { Fiber: PDMS } / \mathrm{DVB}^{\mathrm{s}} \\
\text { EC: } 1 \mathrm{~mL} \mathrm{H}_{2} \mathrm{O}, 20 \mathrm{~min}, 100^{\circ} \mathrm{C}\end{array}$ & $70-124$ & [120] \\
\hline
\end{tabular}

${ }^{a}$ Solid phase extraction; ${ }^{\mathrm{b}}$ Ultrasound assisted extraction; ${ }^{\mathrm{c}}$ Accelerated solvent extraction; ${ }^{\mathrm{d}}$ Pressurized liquid extraction; ${ }^{\mathrm{e}}$ Microwaveassisted extraction; ${ }^{\mathrm{f}}$ Quick, easy, cheap, effective, rugged and safe; ${ }^{\mathrm{g}}$ Solid phase microextraction; ${ }^{\mathrm{h}}$ Sample amount; ${ }^{\mathrm{i}}$ Extraction conditions; ${ }^{j}$ Extraction solvent; ${ }^{k}$ Methanol; ${ }^{1}$ Acetonitrile; ${ }^{m}$ Ethylenediamine tetraacetic acid; ${ }^{n}$ Ammonium chloride; ${ }^{o}$ Disodium ethylenediaminetetraacetate dihydrate; ${ }^{\mathrm{p}}$ Acetonitrile; ${ }^{\mathrm{q}}$ Ethyl acetate; ${ }^{\mathrm{r}}$ Toluene; ${ }^{\mathrm{s}}$ Polydimethylsiloxane/ divinylbenzene. 
Ultrasound assisted extraction (UAE) have been widely used in PCPs present in marine samples. This technique uses the energy of the ultrasounds to transfer the compounds adsorbed on solid samples to an extractant. This means a reduction of extraction times and a lower volume or organic toxic solvents. The organic solvents used to extract PCPs from marine sediments are usually methanol and acetonitrile, in some cases, buffered with an aqueous solution considering the physicochemical properties or the target analytes $[81,85,124,125]$. Some authors reported a duplicate extraction to increase the extraction recovery $[81,123,125,126]$. The extraction recovery was determined based on the relating the known theoretical concentration added to the sample $\left(\mathrm{C}_{\text {theoretical }}\right)$ to the experimental concentration $\left(\mathrm{C}_{\text {experimental }}\right)$ of each PPCPs in the sample, spiked at different concentrations. The $C_{\text {experimental }}$ was calculated based on the variance between the peak areas of the analytes in spiked and non-spiked samples. However, this procedure could promote a dilution of the analytes, consequently additional steps (e.g., evaporation) could be required. Another used extraction techniques for solid samples are based on pressurized solvent extraction (PSE) which involves analyte extraction during short times with solvents at elevated temperatures (up to $200^{\circ} \mathrm{C}$ ) and pressures (up to $3000 \mathrm{psi}$ ) [132]. For the extraction of PCPs from marine solid samples, the different studies suggest the use of methanol, water or a mixture of them at temperatures near boiling point of water $\left(90-100{ }^{\circ} \mathrm{C}\right)$ and extraction pressures around 100 bars. This technique has been used especially for the extraction of PhaCs in multiresidue procedures [102,128,129], which indicate its versatility to compounds with diverse physicochemical properties. Other instrumental extraction technique is microwave assisted extraction (MAE). In this case, the extraction of the analytes from solid samples is induced by the energy associated to microwaves producing a heat of the extraction solvent and partitioning analytes from a sample matrix into the solvent [133]. This is an advantage, especially when it is necessary to heat a solvent mixture rapidly. This methodology has been satisfactorily developed by Montesdeoca-Esponda et al. in sediment samples for the extraction of PCPs such as fluoroquinolone antibiotics or benzotriazole UV stabilizers $[130,131]$. Furthermore, in the extraction of PCPs using MAE, organic solvents used as extractant could be substituted by greener solvents such as micellar solutions with good extraction efficiencies [130].

Due to the complexity of marine solid samples, in many cases it is necessary to perform a clean-up step that consist in a dilution of the extract and a following liquid extraction methodology such as SPE. In this regard, many authors reported the use of a clean-up step based on SPE for the isolation of PCPs present in marine solid samples $[85,102,121,124-126,128,129,131]$. Due to the varied physicochemical characteristics of PPCPs, this clean-up step is usually performed using hydrophilic-hydrophobic polymers such as Oasis HLB.

\subsection{High Resolution Analytical Platforms}

Chromatographic techniques, such as LC coupled to MS or MS/MS are certainly the most frequently analytical platforms for the determination of ECs in environment samples (Tables 4 and 5), mainly when isomeric mixtures are analyzed, providing a higher selectivity. Traditional systems such as LC coupled with different detectors, such as diode array detection (DAD) [116] and fluorescence detector (FLR) [100] have been used to determine 4 benzophenone UV filters and enrofloxacin in environmental waters, respectively. The main advantages of these traditional systems are faster, easier to use, efficient, lowcost and more accessible in common laboratories [100]. Perhaps, the lower sensitivity obtained using these detectors, principally when analyzing complex samples, satisfactory figures of merit were achieved, such as low LODs (few $\mu \mathrm{g} / \mathrm{L})$, high recoveries $(>70 \%)$, good repeatability and reproducibility with relative standard deviations (RSD) lower than $13 \%$. Nowadays, DAD and FLR detectors have been replaced for more selective MS or MS/MS detectors. MS detection allows the addition of multiple labeled internal standards before extraction procedure, which permit more accurate quantification of ECs in environmental samples [124]. 
Liquid chromatography-tandem mass spectrometry (LC-MS/MS) is becoming an emergent analytical platform to determine ECs in environmental samples due to its great separation resolution, ability of identifying compounds, sensitivity (low LODs) and does not require any derivatization procedure previous to the analysis [96-98,104,108,110,123]. However, the main disadvantages of LC-MS/MS is the complexity of operation, cost and strong matrix effects, which promotes in several cases the signal suppression or enhancement $[108,110]$. More sophisticated analytical platforms, namely ultra-performance liquid chromatography tandem mass spectrometry (UHPLC/MS-MS) have been recently applied in the determination of ECs in environmental samples $[68,81,93,102,111,117,119]$. This technique allows higher pressures, narrow peaks, improves chromatographic separation, reduce significantly the time of analysis and solvent volumes [111,131]. MontesdeocaEsponda et al. [117] developed a sensitive UHPLC-MS/MS method that, under optimal conditions, allowed the separation of 7 UV stabilizers in less than 1 min. Nevertheless, the high cost of instrumentation and maintenance are the main drawbacks of this equipment [100]. On the other hand, LC coupled to high resolution mass spectrometry (HRMS) has gained an increased popularity as a powerful analytical platform in the identification of novel emerging micropollutants in the aquatic environmental [134]. LC-HRMS compared do LC-MS with unit mass resolution provides a screening for targeted (using reference standard), suspect (exact mass as a previous information) and non-targeted (no preliminary information) analyses in a single run, generating high-resolution accurate masses, their isotopic patterns and $\mathrm{MS}^{2}$ spectra included in online databases [135]. Related to non-target screening, several authors have been proposed a scheme for reporting the identification confidence, where the interpretation of fragmentation pattern, retention time, mass accuracy, isotopic pattern of the precursor ion are considered as supporting data in the identification and elucidation of chemical structural [134,136,137]. Comtois-Marotte et al. [138] analyzed 31 PPCPs from surface water, wastewater, suspended particulate matter and sediments, being the quantification performed in both full scan, and $\mathrm{MS}^{2}$ modes. Satisfactory figures of merit (recovery, LODs, matrix effect) were achieved, which support the potentiality of LC-HRMS in the identification and quantification of ECs.

Regarding to MS detector, the ECs were common detected and quantified using a triple quadrupole mass spectrometer (QqQMS/MS) equipped with electrospray ionization (ESI) source in multiple reaction monitoring (MRM) mode, with the selection of a precursor ion and two ion products to quantify and qualify each compound $[68,81,96,102,105]$. ESI is a softer ionization technique that provides information on the molecular ion, which can be valuable in ECs determination, being the matrix effect its major drawback. On the other hand, McEneff et al. [97] used an ion trap mass spectrometer equipped with ESI source, in both ESI (+) and ESI (-) mode, in selected reaction monitoring (SRM) to assess the distribution if 5 PhaCs in sewage effluent, receiving marine waters and marine bivalves. Good recoveries ( 56 to $110 \%$ ), low LODs (3 to $225 \mathrm{ng} \mathrm{L}^{-1}$ ) and precision $(\mathrm{RSD}<11 \%)$ were achieved, which demonstrate the potentiality of this analytical platform in the ECs determination.

Gas chromatography (GC) combined with MS [69,99,106,113,139,140] or MS/MS [118,120] has also been used in less proportion, when compared to LC-MS/MS, in the assessment of ECs in environmental samples. A possible explanation for this occurrence can be the total time of analysis as well as the derivatization procedure required in GC analysis to promote the volatility and decrease the polarity of the analytes [106,108]. Possibly, LC systems show low peak capacities and separations when compared to GC that continue to be the preferential analytical platform in the determination of PhaCs and PCPs in environmental matrices due to its cost and availability. The most common chromatographic conditions used are a capillary column coated with $5 \%$ phenyl- $95 \%$ dimethylpolysiloxane, helium as carrier gas at flow 1.0 to $5.5 \mathrm{~mL} \mathrm{~min}^{-1}$, under temperatures program starting from 80 to $300{ }^{\circ} \mathrm{C}$ in a total time of analysis ranging from 9 to $45 \mathrm{~min}$, whereas MS operates at $70 \mathrm{eV}$ in the electron impact (EI) ionization using mode selected ion monitoring (SIM) $[88,106,108,118]$. In case of GC-MS/MS multiple reaction mode (MRM) was used $[113,118]$. All these GC-MS 
showed satisfactory figures of merit in terms of recovery $(>70 \%)$, precision ( $\mathrm{RSD}<10 \%)$, LODs (few ng L ${ }^{-1}$ ) and LOQs (few ng L ${ }^{-1}$ ). In spite of the use of a robust technique (e.g., GC-MS/MS, LC-MS/MS), preconcentration and cleaning techniques are still required to increase the analytical performance [100].

\section{Conclusions and Future Trends}

Emerging pollutants are present in the developed societies and their growing production and continuous introduction in the environment is a fact that needs be faced. Since their concentrations will inevitably grow in the oceans, it is mandatory to know the pathways of entry in the environment, the processes of dilution, precipitation, change or degradation that they suffer, as well as the final accumulation that these products have in each natural compartments.

Advances analytical techniques are required to determine these pollutants at such low concentrations. Extraction techniques that not only isolate but also preconcentrate target analytes from the matrix are required for a reliable identification and quantification. For seawater samples, SPE is the preferred technique, given the easily of the procedure and the variety of different sorbents commercially available that are able to extract pollutants with a wide range of characteristics. The possibility of using lab-made sorbents is also an advantage of this extraction technique. Microextraction techniques have also been used but their efficiencies of the extraction are lower since they are based on equilibrium processes instead to be exhaustive. For solid samples such as sediments, procedures applying high energy conditions such as microwave or pressurised solvent extraction are used to break the interaction between analyte and matrix. Regarding detection techniques LC coupled to MS or MS/MS is the common analytical platform to determine PhaCs and PCPs in environmental samples since showed a great separation resolution, ability of identifying compounds and high sensitivity and does not require any derivatization process previous to the analysis.

Once released to the environment, emerging pollutants will be incorporated and bioaccumulated by the marine organisms depending on their characteristics, being able to biomagnificate them to the upper levels of the food chain reaching even the humans. For this reason, is also important to evaluate the risk associated to the concentrations found in the ocean and assess the hazard for different coastal species. The combined effect of different emerging pollutants must be also taken into consideration, given the synergists that could occur.

According to the reviewed literature, the information regarding the toxicity of PhaCs and specially of PCPs towards marine species are still very scarce. Thus, the environmental risk assessment is often carried out considering ecotoxicological data for freshwater organisms. This risk evaluation also has limitations, such as the lack of reliable of long-term toxicological studies and the difficulty in carrying out chronic studies during the life of some organisms. Moreover, since a mixture of pollutants is present in the environment, synergistic effects could be expected, resulting in a risk greater than that calculated.

It is noticeable that there is a lack of information regarding the fate and impact of some PhaCs and PCPs in the environment, so efforts must be focused on the study of the occurrence and risk of all families of emerging compounds to obtain a whole picture of the problem.

Given the main entry of these pollutants is related to sewage discharges, parallel research should be carried out to develop more efficient treatment systems and monitoring programmes, especially for indispensable pharmaceuticals.

Regarding the ingredients of PCPs, the most urgent issue is identifying the more dangerous substances and find more biodegradable replacement for them. In this sense, it is expected that countries will follow the trend driven by several normatives implemented to protect the environment, for example, the ban of some UV filters.

Author Contributions: All co-authors contributed equally for this manuscript. J.S.C. planned the manuscript; S.M.-E. was responsible for Section 1; J.F. and J.S.C. written the Sections 2, 2.1 and 2.2; 
R.G.-A. and Z.S.-F. were responsible for all Sections 3 and 4.1; R.P. was responsible by Section 4.2. R.P., S.M.-E., and J.S.C. edited the manuscript and J.S.C. did its submission. All authors have read and agreed to the published version of the manuscript.

Funding: This work was supported by FCT-Fundação para a Ciência e a Tecnologia through the CQM Base Fund-UIDB/00674/2020, and Programmatic Fund-UIDP/00674/2020, and by ARDITIAgência Regional para o Desenvolvimento da Investigação Tecnologia e Inovação, through the project M1420-01-0145-FEDER-000005-Centro de Química da Madeira-CQM+ (Madeira 14-20 Program). The authors also acknowledge the financial support from Fundação para a Ciência e Tecnologia and Madeira 14-2020 program to the Portuguese Mass Spectrometry Network through PROEQUI-PRAM program, M14-20 M1420-01-0145-FEDER-000008

Institutional Review Board Statement: Not Applicable.

Informed Consent Statement: Not Applicable.

Data Availability Statement: Not applicable.

Conflicts of Interest: The authors declare no conflict of interest.

\section{References}

1. United Nations. The Ocean Conference-Fact Sheet Package, New York, NY, USA. 2017. Available online: https: //sustainabledevelopment.un.org/content/documents/Ocean_Factsheet_People.pdf (accessed on 15 March 2021).

2. Mora, C.; Tittensor, D.P.; Adl, S.; Simpson, A.G.B.; Worm, B. How many species are there on earth and in the ocean? PLoS Biol. 2011, 9, e1001127. [CrossRef]

3. Creel, L. Ripple Effects: Population and Coastal Regions; Population Reference Bureau: Washington, DC, USA, 2003.

4. Berne, S.; Marchand, M.; D'Ozouville, L. Pollution of Sea Water and Marine Sediments in Coastal Areas. Ambio 1980, 9, $287-293$.

5. Richardson, S.D. Water analysis: Emerging contaminants and current issues. Anal. Chem. 2009, 81, 4645-4677. [CrossRef]

6. Deblonde, T.; Cossu-Leguille, C.; Hartemann, P. Emerging pollutants in wastewater: A review of the literature. Int. J. Hyg. Environ. Health 2011, 214, 442-448. [CrossRef] [PubMed]

7. Gavrilescu, M.; Demnerová, K.; Aamand, J.; Agathos, S.; Fava, F. Emerging pollutants in the environment: Present and future challenges in biomonitoring, ecological risks and bioremediation. N. Biotechnol. 2015, 32, 147-156. [CrossRef]

8. Geissen, V.; Mol, H.; Klumpp, E.; Umlauf, G.; Nadal, M.; van der Ploeg, M.; van de Zee, S.E.A.T.M.; Ritsema, C.J. Emerging pollutants in the environment: A challenge for water resource management. Int. Soil Water Conserv. Res. 2015, 3, 57-65. [CrossRef]

9. Küster, A.; Adler, N. Pharmaceuticals in the environment: Scientific evidence of risks and its regulation. Philos. Trans. R. Soc. B Biol. Sci. 2014, 369. [CrossRef]

10. Boxall, A.B.A.; Rudd, M.A.; Brooks, B.W.; Caldwell, D.J.; Choi, K.; Hickmann, S.; Innes, E.; Ostapyk, K.; Staveley, J.P.; Verslycke, T.; et al. Pharmaceuticals and personal care products in the environment: What are the big questions? Environ. Health Perspect. 2012, 120, 1221-1229. [CrossRef] [PubMed]

11. Ebele, A.J.; Abou-Elwafa Abdallah, M.; Harrad, S. Pharmaceuticals and personal care products (PPCPs) in the freshwater aquatic environment. Emerg. Contam. 2017, 3, 1-16. [CrossRef]

12. Richardson, B.J.; Lam, P.K.S.; Martin, M. Emerging chemicals of concern: Pharmaceuticals and personal care products (PPCPs) in Asia, with particular reference to Southern China. Mar. Pollut. Bull. 2005, 50, 913-920. [CrossRef]

13. Mostofa, K.M.G.; Liu, C.Q.; Vione, D.; Gao, K.; Ogawa, H. Sources, factors, mechanisms and possible solutions to pollutants in marine ecosystems. Environ. Pollut. 2013, 182, 461-478. [CrossRef]

14. Mearns, A.J.; Reish, D.J.; Oshida, P.S.; Morrison, A.M.; Rempel-Hester, M.A.; Arthur, C.; Rutherford, N.; Pryor, R. Effects of pollution on marine organisms. Water Environ. Res. 2016, 88, 1693-1807. [CrossRef]

15. Branchet, P.; Arpin-Pont, L.; Piram, A.; Boissery, P.; Wong-Wah-Chung, P.; Doumenq, P. Pharmaceuticals in the marine environment: What are the present challenges in their monitoring? Sci. Total Environ. 2021, 766, 142644. [CrossRef] [PubMed]

16. Bertram, C.; Rehdanz, K. On the environmental effectiveness of the EU marine strategy framework directive. Mar. Policy 2013, 38, 25-40. [CrossRef]

17. Juda, L. The European Union and the Marine Strategy Framework Directive: Continuing the development of European ocean use management. Ocean Dev. Int. Law 2010, 41, 34-54. [CrossRef]

18. Carere, M.; Polesello, S.; Kase, R.; Gawlik, B.M. The emerging contaminants in the context of the EU water framework directive. Handb. Environ. Chem. 2016, 46, 197-215. [CrossRef]

19. Fliedner, A.; Rüdel, H.; Dreyer, A.; Pirntke, U.; Koschorreck, J. Chemicals of emerging concern in marine specimens of the German Environmental Specimen Bank. Environ. Sci. Eur. 2020, 32, 36. [CrossRef]

20. Hutchinson, T.H.; Lyons, B.P.; Thain, J.E.; Law, R.J. Evaluating legacy contaminants and emerging chemicals in marine environments using adverse outcome pathways and biological effects-directed analysis. Mar. Pollut. Bull. 2013, 74, 517-525. [CrossRef] [PubMed] 
21. Muñoz, I.; López-Doval, J.C.; De Castro-Català, N.; Kuzmanovic, M.; Ginebreda, A.; Sabater, S. Effects of emerging contaminants on biodiversity, community structure, and adaptation of river biota. Handb. Environ. Chem. 2016, 46, 79-119. [CrossRef]

22. Brumovský, M.; Bečanová, J.; Kohoutek, J.; Borghini, M.; Nizzetto, L. Contaminants of emerging concern in the open sea waters of the Western Mediterranean. Environ. Pollut. 2017, 229, 976-983. [CrossRef] [PubMed]

23. Cunha, I.; Oliveira, H.; Neuparth, T.; Torres, T.; Santos, M.M. Fate, behaviour and weathering of priority HNS in the marine environment: An online tool. Mar. Pollut. Bull. 2016, 111, 330-338. [CrossRef]

24. Tornero, V.; Hanke, G. Chemical contaminants entering the marine environment from sea-based sources: A review with a focus on European seas. Mar. Pollut. Bull. 2016, 112, 17-38. [CrossRef]

25. Sauvé, S.; Desrosiers, M. A review of what is an emerging contaminant. Chem. Cent. J. 2014, 8, 15. [CrossRef] [PubMed]

26. Zaborska, A.; Siedlewicz, G.; Szymczycha, B.; Dzierzbicka-Głowacka, L.; Pazdro, K. Legacy and emerging pollutants in the Gulf of Gdańsk (southern Baltic Sea)—Loads and distribution revisited. Mar. Pollut. Bull. 2019, 139, 238-255. [CrossRef]

27. Jiang, J.J.; Lee, C.L.; Fang, M. Der Emerging organic contaminants in coastal waters: Anthropogenic impact, environmental release and ecological risk. Mar. Pollut. Bull. 2014, 85, 391-399. [CrossRef] [PubMed]

28. Rodríguez-Mozaz, S.; Huerta, B.; Barceló, D. Bioaccumulation of emerging contaminants in aquatic biota: Patterns of pharmaceuticals in mediterranean river networks. Handb. Environ. Chem. 2016, 46, 121-141. [CrossRef]

29. Scott, G.I.; Porter, D.E.; Norman, R.S.; Scott, C.H.; Uyaguari-Diaz, M.I.; Maruya, K.A.; Weisberg, S.B.; Fulton, M.H.; Wirth, E.F.; Moore, J.; et al. Antibiotics as CECs: An overview of the hazards posed by antibiotics and antibiotic resistance. Front. Mar. Sci. 2016, 3, 24. [CrossRef]

30. Krogh, J.; Lyons, S.; Lowe, C.J. Pharmaceuticals and personal care products in municipal wastewater and the marine receiving environment near Victoria Canada. Front. Mar. Sci. 2017, 4, 415. [CrossRef]

31. Srikanth, K. Emerging contaminants effect on aquatic ecosystem: Human health risks. Agric. Res. Technol. Open Access J. 2019, 19, 1-6. [CrossRef]

32. Pawar, P.R.; Shirgaonkar, S.S.; Patil, R.B. Plastic marine debris: Sources, distribution and impacts on coastal and ocean biodiversity. PENCIL Publ. Biol. Sci. Oceanogr. 2016, 3, 40-54.

33. Mezzelani, M.; Gorbi, S.; Regoli, F. Pharmaceuticals in the aquatic environments: Evidence of emerged threat and future challenges for marine organisms. Mar. Environ. Res. 2018, 140, 41-60. [CrossRef] [PubMed]

34. Grigorakis, K.; Rigos, G. Aquaculture effects on environmental and public welfare-The case of Mediterranean mariculture. Chemosphere 2011, 85, 899-919. [CrossRef] [PubMed]

35. UNESCO. Pharmaceuticals in the Aquatic Environment of the Baltic Sea Region-A Status Report; UNESCO: Paris, France, 2017.

36. Martínez, M.L.; Intralawan, A.; Vázquez, G.; Pérez-Maqueo, O.; Sutton, P.; Landgrave, R. The coasts of our world: Ecological, economic and social importance. Ecol. Econ. 2007, 63, 254-272. [CrossRef]

37. Gaw, S.; Thomas, K.V.; Hutchinson, T.H. Sources, impacts and trends of pharmaceuticals in the marine and coastal environment. Philos. Trans. R. Soc. B Biol. Sci. 2014, 369, 20130572. [CrossRef] [PubMed]

38. Quintiles IMS Global Medicines Use in 2020: Outlook and Implications. Available online: https://pt.slideshare.net/IMSHealth1 / global-medicines-use-in-2020-outlook-and-implications (accessed on 5 May 2021).

39. Cortez, F.S.; Seabra Pereira, C.D.; Santos, A.R.; Cesar, A.; Choueri, R.B.; Martini, G.D.A.; Bohrer-Morel, M.B. Biological effects of environmentally relevant concentrations of the pharmaceutical Triclosan in the marine mussel Perna perna (Linnaeus, 1758). Environ. Pollut. 2012, 168, 145-150. [CrossRef]

40. Ojemaye, C.Y.; Petrik, L. Pharmaceuticals in the marine environment: A review. Environ. Rev. 2019, 27, 151-165. [CrossRef]

41. Gilbert, E.; Pirot, F.; Bertholle, V.; Roussel, L.; Falson, F.; Padois, K. Commonly used UV filter toxicity on biological functions: Review of last decade studies. Int. J. Cosmet. Sci. 2013, 35, 208-219. [CrossRef]

42. Stiefel, C.; Schwack, W. Photoprotection in changing times-UV filter efficacy and safety, sensitization processes and regulatory aspects. Int. J. Cosmet. Sci. 2015, 37, 2-30. [CrossRef] [PubMed]

43. Ternes, T.A.T.A.; Joss, A.; Siegrist, H. Scrutinizing pharmaceuticals and personal care products in wastewater treatment. Environ. Sci. Technol. 2004, 38, 392A-399A. [CrossRef]

44. Gao, Y.; Li, G.; Ma, S.; An, T. Research progress and challenge of synthetic musks: From personal care, environment pollution to human health. Prog. Chem. 2017, 29, 1082-1092.

45. Mackay, D.; Barnthouse, L. Integrated risk assessment of household chemicals and consumer products: Addressing concerns about triclosan. Integr. Environ. Assess. Manag. 2010, 6, 390-392. [CrossRef]

46. Peck, A.M. Analytical methods for the determination of persistent ingredients of personal care products in environmental matrices. Anal. Bioanal. Chem. 2006, 386, 907-939. [CrossRef] [PubMed]

47. Ojemaye, C.Y.; Petrik, L. Pharmaceuticals and personal care product in the marine environment around False Bay, Cape Town, South Africa: Occurrence and risk assessment study. Environ. Toxicol. Chem. 2021. [CrossRef] [PubMed]

48. Brausch, J.M.; Rand, G.M. A review of personal care products in the aquatic environment: Environmental concentrations and toxicity. Chemosphere 2011, 82, 1518-1532. [CrossRef]

49. Alonso, M.B.; Feo, M.L.; Corcellas, C.; Gago-Ferrero, P.; Bertozzi, C.P.; Marigo, J.; Flach, L.; Meirelles, A.C.O.; Carvalho, V.L.; Azevedo, A.F.; et al. Toxic heritage: Maternal transfer of pyrethroid insecticides and sunscreen agents in dolphins from Brazil. Environ. Pollut. 2015, 207, 391-402. [CrossRef] 
50. Kim, J.W.; Ramaswamy, B.R.; Chang, K.H.; Isobe, T.; Tanabe, S. Multiresidue analytical method for the determination of antimicrobials, preservatives, benzotriazole UV stabilizers, flame retardants and plasticizers in fish using ultra high performance liquid chromatography coupled with tandem mass spectrometry. J. Chromatogr. A 2011, 1218, 3511-3520. [CrossRef]

51. Han, E.J.; Lee, D.S. Significance of metabolites in the environmental risk assessment of pharmaceuticals consumed by human. Sci. Total Environ. 2017, 592, 600-607. [CrossRef] [PubMed]

52. Tovar-Sánchez, A.; Sánchez-Quiles, D.; Basterretxea, G.; Benedé, J.L.; Chisvert, A.; Salvador, A.; Moreno-Garrido, I.; Blasco, J. Sunscreen products as emerging pollutants to coastal waters. PLoS ONE 2013, 8, e65451. [CrossRef] [PubMed]

53. Lacerda, D.; Vergilio, C.; Dos, S.; da Silva Souza, T.; Viana Costa, L.H.; Rangel, T.P.; Vaz de Oliveira, B.C.; Ribeiro de Almeida, D.Q.; Pestana, I.A.; Gomes de Almeida, M.; et al. Comparative metal accumulation and toxicogenetic damage induction in three neotropical fish species with distinct foraging habits and feeding preferences. Ecotoxicol. Environ. Saf. 2020, 195, 110449. [CrossRef]

54. Gago-Ferrero, P.; Díaz-Cruz, M.S.; Barceló, D. An overview of UV-absorbing compounds (organic UV filters) in aquatic biota. Anal. Bioanal. Chem. 2012, 404, 2597-2610. [CrossRef]

55. Ng, B.; Quinete, N.; Maldonado, S.; Lugo, K.; Purrinos, J.; Briceño, H.; Gardinali, P. Understanding the occurrence and distribution of emerging pollutants and endocrine disruptors in sensitive coastal South Florida Ecosystems. Sci. Total Environ. 2021, 757, 143720. [CrossRef] [PubMed]

56. Queirós, V.; Azeiteiro, U.M.; Soares, A.M.V.M.; Freitas, R. The antineoplastic drugs cyclophosphamide and cisplatin in the aquatic environment-Review. J. Hazard. Mater. 2021, 412, 125028. [CrossRef] [PubMed]

57. Nogueira, A.F.; Nunes, B. Effects of paracetamol on the polychaete Hediste diversicolor: Occurrence of oxidative stress, cyclooxygenase inhibition and behavioural alterations. Environ. Sci. Pollut. Res. 2021, 28, 26772-26783. [CrossRef]

58. Paulson, J.R.; Mahmoud, I.Y.; Al-Musharafi, S.K.; Al-Bahry, S.N. Antibiotic resistant bacteria in the environment as bio-indicators of pollution. Open Biotechnol. J. 2016, 10, 342-351. [CrossRef]

59. Smaldone, G.; Marrone, R.; Cappiello, S.; Martin, G.A.; Oliva, G.; Cortesi, M.L.; Anastasio, A. Occurrence of antibiotic resistance in bacteria isolated from seawater organisms caught in Campania Region: Preliminary study. BMC Vet. Res. 2014, 10. [CrossRef]

60. Molins-Delgado, D.; Gago-Ferrero, P.; Díaz-Cruz, M.S.; Barceló, D. Single and joint ecotoxicity data estimation of organic UV filters and nanomaterials toward selected aquatic organisms. Urban groundwater risk assessment. Environ. Res. 2016, 145, 126-134. [CrossRef] [PubMed]

61. Kaiser, D.; Sieratowicz, A.; Zielke, H.; Oetken, M.; Hollert, H.; Oehlmann, J. Ecotoxicological effect characterisation of widely used organic UV filters. Environ. Pollut. 2012, 163, 84-90. [CrossRef]

62. He, T.; Tsui, M.M.P.; Tan, C.J.; Ng, K.Y.; Guo, F.W.; Wang, L.H.; Chen, T.H.; Fan, T.Y.; Lam, P.K.S.; Murphy, M.B. Comparative toxicities of four benzophenone ultraviolet filters to two life stages of two coral species. Sci. Total Environ. 2019, 651, $2391-2399$. [CrossRef] [PubMed]

63. Adler, B.L.; DeLeo, V.A. Sunscreen safety: A review of recent studies on humans and the environment. Curr. Dermatol. Rep. 2020, 9, 1-9. [CrossRef]

64. Merola, C.; Lucon-Xiccato, T.; Bertolucci, C.; Perugini, M. Behavioural effects of early-life exposure to parabens in zebrafish larvae. J. Appl. Toxicol. 2021. [CrossRef]

65. Mezzelani, M.; Nardi, A.; Bernardini, I.; Milan, M.; Peruzza, L.; d’Errico, G.; Fattorini, D.; Gorbi, S.; Patarnello, T.; Regoli, F. Environmental pharmaceuticals and climate change: The case study of carbamazepine in $\mathrm{M}$. galloprovincialis under ocean acidification scenario. Environ. Int. 2021, 146, 106269. [CrossRef] [PubMed]

66. Sadutto, D.; Andreu, V.; Ilo, T.; Akkanen, J.; Picó, Y. Pharmaceuticals and personal care products in a Mediterranean coastal wetland: Impact of anthropogenic and spatial factors and environmental risk assessment. Environ. Pollut. 2021, 271. [CrossRef]

67. Sanderson, H.; Johnson, D.J.; Wilson, C.J.; Brain, R.A.; Solomon, K.R. Probabilistic hazard assessment of environmentally occurring pharmaceuticals toxicity to fish, daphnids and algae by ECOSAR screening. Toxicol. Lett. 2003, 144, 383-395. [CrossRef]

68. Biel-Maeso, M.; Baena-Nogueras, R.M.; Corada-Fernández, C.; Lara-Martín, P.A. Occurrence, distribution and environmental risk of pharmaceutically active compounds (PhACs) in coastal and ocean waters from the Gulf of Cadiz (SW Spain). Sci. Total Environ. 2018, 612, 649-659. [CrossRef] [PubMed]

69. Lolić, A.; Paíga, P.; Santos, L.H.M.L.M.; Ramos, S.; Correia, M.; Delerue-Matos, C. Assessment of non-steroidal anti-inflammatory and analgesic pharmaceuticals in seawaters of North of Portugal: Occurrence and environmental risk. Sci. Total Environ. 2015, 508, 240-250. [CrossRef] [PubMed]

70. Espinosa-Ruiz, C.; Manuguerra, S.; Morghese, M.; García-Beltrán, J.M.; Esteban, M.Á.; Giuga, M.; Messina, C.M.; Santulli, A. Immunity and inflammatory responses in gilthead sea bream (Sparus aurata L.) exposed to sub-lethal mixture of carbamazepine, cadmium chloride and polybrominated diphenyl ether. Fish Shellfish Immunol. 2021, 111, 25-35. [CrossRef]

71. Świacka, K.; Michnowska, A.; Maculewicz, J.; Caban, M.; Smolarz, K. Toxic effects of NSAIDs in non-target species: A review from the perspective of the aquatic environment. Environ. Pollut. 2021, 273. [CrossRef] [PubMed]

72. European Commission Technical Guidance Documentin support of Commission Directive93/67/EEC on Risk Assessment for new notifieds ubstances, Commission Regulation (EC) No1488/94 on Risk Assessment for existing substances, Directive 98/8/EC of the Euro. 2003. Available online: https:/ / echa.europa.eu/documents/10162/16960216/tgdpart2_2ed_en.pdf (accessed on 1 June 2021). 
73. Thomaidi, V.S.; Stasinakis, A.S.; Borova, V.L.; Thomaidis, N.S. Is there a risk for the aquatic environment due to the existence of emerging organic contaminants in treated domestic wastewater? Greece as a case-study. J. Hazard. Mater. 2015, 283, 740-747. [CrossRef] [PubMed]

74. European Medicines Agency. Environmental Risk Assessment of Medicinal Products for Human Use. 2006. Available online: https:/ / www.ema.europa.eu/en/documents/scientific-guideline/guideline-environmental-risk-assessment-medicinalproducts-human-use-first-version_en.pdf (accessed on 1 March 2021).

75. Ramaswamy, B.R.; Shanmugam, G.; Velu, G.; Rengarajan, B.; Larsson, D.G.J. GC-MS analysis and ecotoxicological risk assessment of triclosan, carbamazepine and parabens in Indian rivers. J. Hazard. Mater. 2011, 186, 1586-1593. [CrossRef]

76. Pusceddu, F.H.; Choueri, R.B.; Pereira, C.D.S.; Cortez, F.S.; Santos, D.R.A.; Moreno, B.B.; Santos, A.R.; Rogero, J.R.; Cesar, A. Environmental risk assessment of triclosan and ibuprofen in marine sediments using individual and sub-individual endpoints. Environ. Pollut. 2018, 232, 274-283. [CrossRef] [PubMed]

77. Park, S.; Choi, K. Hazard assessment of commonly used agricultural antibiotics on aquatic ecosystems. Ecotoxicology 2008, 17, 526-538. [CrossRef] [PubMed]

78. Molins-Delgado, D.; Díaz-Cruz, M.S.; Barceló, D. Ecological risk assessment associated to the removal of endocrine-disrupting parabens and benzophenone-4 in wastewater treatment. J. Hazard. Mater. 2016, 310, 143-151. [CrossRef] [PubMed]

79. Zhou, L.; Fan, D.; Yin, W.; Gu, W.; Wang, Z.; Liu, J.; Xu, Y.; Shi, L.; Liu, M.; Ji, G. Comparison of seven in silico tools for evaluating of daphnia and fish acute toxicity: Case study on Chinese priority controlled chemicals and new chemicals. BMC Bioinform. 2021, 22, 151. [CrossRef]

80. Roveri, V.; Guimarães, L.L.; Toma, W.; Correia, A.T. Occurrence and risk assessment of pharmaceuticals and cocaine around the coastal submarine sewage outfall in Guarujá, São Paulo State, Brazil. Environ. Sci. Pollut. Res. 2021, 28, 11384-11400. [CrossRef]

81. Li, F.; Chen, L.; Chen, W.; Bao, Y.; Zheng, Y.; Huang, B.; Mu, Q.; Wen, D.; Feng, C. Antibiotics in coastal water and sediments of the East China Sea: Distribution, ecological risk assessment and indicators screening. Mar. Pollut. Bull. 2020, 151, 110810. [CrossRef]

82. Vazquez-Roig, P.; Andreu, V.; Blasco, C.; Picó, Y. Risk assessment on the presence of pharmaceuticals in sediments, soils and waters of the Pego-Oliva Marshlands (Valencia, eastern Spain). Sci. Total Environ. 2012, 440, 24-32. [CrossRef]

83. Allinson, M.; Kameda, Y.; Kimura, K.; Allinson, G. Occurrence and assessment of the risk of ultraviolet filters and light stabilizers in Victorian estuaries. Environ. Sci. Pollut. Res. 2018, 25, 12022-12033. [CrossRef] [PubMed]

84. Montesdeoca-Esponda, S.; Álvarez-Raya, C.; Torres-Padrón, M.E.; Sosa-Ferrera, Z.; Santana-Rodríguez, J.J. Monitoring and environmental risk assessment of benzotriazole UV stabilizers in the sewage and coastal environment of Gran Canaria (Canary Islands, Spain). J. Environ. Manag. 2019, 233, 567-575. [CrossRef] [PubMed]

85. Azaroff, A.; Miossec, C.; Lanceleur, L.; Guyoneaud, R.; Monperrus, M. Priority and emerging micropollutants distribution from coastal to continental slope sediments: A case study of Capbreton Submarine Canyon (North Atlantic Ocean). Sci. Total Environ. 2020, 703, 135057. [CrossRef]

86. Capolupo, M.; Díaz-Garduño, B.; Martín-Díaz, M.L. The impact of propranolol, $17 \alpha$-ethinylestradiol, and gemfibrozil on early life stages of marine organisms: Effects and risk assessment. Environ. Sci. Pollut. Res. 2018, 25, 32196-32209. [CrossRef]

87. Gros, M.; Petrović, M.; Ginebreda, A.; Barceló, D. Removal of pharmaceuticals during wastewater treatment and environmental risk assessment using hazard indexes. Environ. Int. 2010, 36, 15-26. [CrossRef] [PubMed]

88. Singh, K.P.; Rai, P.; Singh, A.K.; Verma, P.; Gupta, S. Occurrence of pharmaceuticals in urban wastewater of north Indian cities and risk assessment. Environ. Monit. Assess. 2014, 186, 6663-6682. [CrossRef]

89. Huber, S.; Remberger, M.; Kaj, L.; Schlabach, M.; Jörundsdóttir, H.T.; Vester, J.; Arnórsson, M.; Mortensen, I.; Schwartson, R.; Dam, M. A first screening and risk assessment of pharmaceuticals and additives in personal care products in waste water, sludge, recipient water and sediment from Faroe Islands, Iceland and Greenland. Sci. Total Environ. 2016, 562, 13-25. [CrossRef]

90. Dimpe, K.M.; Nomngongo, P.N. Current sample preparation methodologies for analysis of emerging pollutants in different environmental matrices. Trends Anal. Chem. 2016, 82, 199-207. [CrossRef]

91. Sadutto, D.; Picó, Y. Sample preparation to determine pharmaceutical and personal care products in an all-water matrix: Solid phase extraction. Molecules 2020, 25, 5204. [CrossRef]

92. Dehm, J.; Singh, S.; Ferreira, M.; Piovano, S.; Fick, J. Screening of pharmaceuticals in coastal waters of the southern coast of Viti Levu in Fiji, South Pacific. Chemosphere 2021, 276, 130161. [CrossRef] [PubMed]

93. Bao, Y.; Li, F.; Chen, L.; Mu, Q.; Huang, B.; Wen, D. Fate of antibiotics in engineered wastewater systems and receiving water environment: A case study on the coast of Hangzhou Bay, China. Sci. Total Environ. 2021, 769, 144642. [CrossRef]

94. Petrović, M.; Hernando, M.D.; Díaz-Cruz, M.S.; Barceló, D. Liquid chromatography-tandem mass spectrometry for the analysis of pharmaceutical residues in environmental samples: A review. J. Chromatogr. A 2005, 1067, 1-14. [CrossRef] [PubMed]

95. Munaron, D.; Tapie, N.; Budzinski, H.; Andral, B.; Gonzalez, J.L. Pharmaceuticals, alkylphenols and pesticides in Mediterranean coastal waters: Results from a pilot survey using passive samplers. Estuar. Coast. Shelf Sci. 2012, 114, 82-92. [CrossRef]

96. Pereira, C.D.S.; Maranho, L.A.; Cortez, F.S.; Pusceddu, F.H.; Santos, A.R.; Ribeiro, D.A.; Cesar, A.; Guimarães, L.L. Occurrence of pharmaceuticals and cocaine in a Brazilian coastal zone. Sci. Total Environ. 2016, 548-549, 148-154. [CrossRef]

97. McEneff, G.; Barron, L.; Kelleher, B.; Paull, B.; Quinn, B. A year-long study of the spatial occurrence and relative distribution of pharmaceutical residues in sewage effluent, receiving marine waters and marine bivalves. Sci. Total Environ. 2014, 476-477, 317-326. [CrossRef] 
98. Spongberg, A.L.; Witter, J.D.; Acuña, J.; Vargas, J.; Murillo, M.; Umaña, G.; Gómez, E.; Perez, G. Reconnaissance of selected PPCP compounds in Costa Rican surface waters. Water Res. 2011, 45, 6709-6717. [CrossRef]

99. Singh, S.P.; Azua, A.; Chaudhary, A.; Khan, S.; Willett, K.L.; Gardinali, P.R. Occurrence and distribution of steroids, hormones and selected pharmaceuticals in South Florida coastal environments. Ecotoxicology 2010, 19, 338-350. [CrossRef]

100. Dias, R.A.S.; Sousa, E.R.; Silva, G.S.; Silva, L.K.; Freitas, A.S.; Lima, D.L.D.; Sousa, É.M.L. Ultrasound-assisted dispersive liquid-liquid microextraction for determination of enrofloxacin in surface waters. Microchem. J. 2021, 160, 105633. [CrossRef]

101. Yang, Y.; Fu, J.; Peng, H.; Hou, L.; Liu, M.; Zhou, J.L. Occurrence and phase distribution of selected pharmaceuticals in the Yangtze Estuary and its coastal zone. J. Hazard. Mater. 2011, 190, 588-596. [CrossRef] [PubMed]

102. Moreno-González, R.; Rodriguez-Mozaz, S.; Gros, M.; Barceló, D.; León, V.M. Seasonal distribution of pharmaceuticals in marine water and sediment from a mediterranean coastal lagoon (SE Spain). Environ. Res. 2015, 138, 326-344. [CrossRef] [PubMed]

103. Hidayati, N.V.; Syakti, A.D.; Asia, L.; Lebarillier, S.; Khabouchi, I.; Widowati, I.; Sabdono, A.; Piram, A.; Doumenq, P. Emerging contaminants detected in aquaculture sites in Java, Indonesia. Sci. Total Environ. 2021, 773, 145057. [CrossRef] [PubMed]

104. Bayen, S.; Zhang, H.; Desai, M.M.; Ooi, S.K.; Kelly, B.C. Occurrence and distribution of pharmaceutically active and endocrine disrupting compounds in Singapore's marine environment: Influence of hydrodynamics and physical-chemical properties. Environ. Pollut. 2013, 182, 1-8. [CrossRef] [PubMed]

105. Dougherty, J.A.; Swarzenski, P.W.; Dinicola, R.S.; Reinhard, M. Occurrence of herbicides and pharmaceutical and personal care products in surface water and groundwater around Liberty Bay, Puget Sound, Washington. J. Environ. Qual. 2010, 39, 1173-1180. [CrossRef] [PubMed]

106. Emnet, P.; Gaw, S.; Northcott, G.; Storey, B.; Graham, L. Personal care products and steroid hormones in the Antarctic coastal environment associated with two Antarctic research stations, McMurdo Station and Scott Base. Environ. Res. 2015, 136, 331-342. [CrossRef]

107. Nödler, K.; Voutsa, D.; Licha, T. Polar organic micropollutants in the coastal environment of different marine systems. Mar. Pollut. Bull. 2014, 85, 50-59. [CrossRef]

108. Huang, S.; Zhu, F.; Jiang, R.; Zhou, S.; Zhu, D.; Liu, H.; Ouyang, G. Determination of eight pharmaceuticals in an aqueous sample using automated derivatization solid-phase microextraction combined with gas chromatography-mass spectrometry. Talanta 2015, 136, 198-203. [CrossRef] [PubMed]

109. Wang, Y.; Jie, Y.; Hu, Q.; Yang, Y.; Ye, Y.; Zou, S.; Xu, J.; Ouyang, G. A polymeric solid-phase microextraction fiber for the detection of pharmaceuticals in water samples. J. Chromatogr. A 2020, 1623, 461171. [CrossRef] [PubMed]

110. Mijangos, L.; Ziarrusta, H.; Olivares, M.; Zuloaga, O.; Möder, M.; Etxebarria, N.; Prieto, A. Simultaneous determination of 41 multiclass organic pollutants in environmental waters by means of polyethersulfone microextraction followed by liquid chromatography-tandem mass spectrometry. Anal. Bioanal. Chem. 2018, 410, 615-632. [CrossRef]

111. Tarazona, I.; Chisvert, A.; León, Z.; Salvador, A. Determination of hydroxylated benzophenone UV filters in sea water samples by dispersive liquid-liquid microextraction followed by gas chromatography-mass spectrometry. J. Chromatogr. A 2010, 1217, 4771-4778. [CrossRef] [PubMed]

112. Benedé, J.L.; Chisvert, A.; Salvador, A.; Sánchez-Quiles, D.; Tovar-Sánchez, A. Determination of UV filters in both soluble and particulate fractions of seawaters by dispersive liquid-liquid microextraction followed by gas chromatography-mass spectrometry. Anal. Chim. Acta 2014, 812, 50-58. [CrossRef]

113. Ramos, S.; Homem, V.; Santos, L. Simultaneous determination of synthetic musks and UV-filters in water matrices by dispersive liquid-liquid microextraction followed by gas chromatography tandem mass-spectrometry. J. Chromatogr. A 2019, 1590, 47-57. [CrossRef]

114. Ku, P.C.; Liu, T.Y.; Lee, S.H.; Kung, T.A.; Wang, W.H. An environmentally friendly strategy for determining organic ultraviolet filters in seawater using liquid-phase microextraction with liquid chromatography-tandem mass spectrometry. Environ. Sci. Pollut. Res. 2020, 27, 9818-9825. [CrossRef] [PubMed]

115. Montesdeoca-Esponda, S.; Sosa-Ferrera, Z.; Santana-Rodríguez, J.J.J.J. On-line solid-phase extraction coupled to ultra-performance liquid chromatography with tandem mass spectrometry detection for the determination of benzotriazole UV stabilizers in coastal marine and wastewater samples. Anal. Bioanal. Chem. 2012, 403, 867-876. [CrossRef] [PubMed]

116. Almeida, C.; Stepkowska, A.; Alegre, A.; Nogueira, J.M.F. Determination of trace levels of benzophenone-type ultra-violet filters in real matrices by bar adsorptive micro-extraction using selective sorbent phases. J. Chromatogr. A 2013, 1311, 1-10. [CrossRef]

117. Montesdeoca-Esponda, S.; Del Toro-Moreno, A.; Sosa-Ferrera, Z.; Santana-Rodríguez, J.J. Development of a sensitive determination method for benzotriazole UV stabilizers in enviromental water samples with stir bar sorption extraction and liquid desorption prior to ultra-high performance liquid chromatography with tandem mass spectrometry. J. Sep. Sci. 2013, 36, 2168-2175. [CrossRef]

118. Vila, M.; Pablo Lamas, J.; Garcia-Jares, C.; Dagnac, T.; Llompart, M. Ultrasound-assisted emulsification microextraction followed by gas chromatography-mass spectrometry and gas chromatography-tandem mass spectrometry for the analysis of UV filters in water. Microchem. J. 2016, 124, 530-539. [CrossRef]

119. García-Guerra, R.B.; Montesdeoca-Esponda, S.; Sosa-Ferrera, Z.; Kabir, A.; Furton, K.G.; Santana-Rodríguez, J.J. Rapid monitoring of residual UV-stabilizers in seawater samples from beaches using fabric phase sorptive extraction and UHPLC-MS/MS Chemosphere 2016, 164, 201-207. [CrossRef] [PubMed] 
120. Vila, M.; Llompart, M.; Garcia-Jares, C.; Homem, V.; Dagnac, T. Development and optimization of a solid-phase microextraction gas chromatography-tandem mass spectrometry methodology to analyse ultraviolet filters in beach sand. J. Chromatogr. A 2018, 1564, 59-68. [CrossRef] [PubMed]

121. Liao, C.; Lee, S.; Moon, H.B.; Yamashita, N.; Kannan, K. Parabens in sediment and sewage sludge from the United States, Japan, and Korea: Spatial distribution and temporal trends. Environ. Sci. Technol. 2013, 47, 10895-10902. [CrossRef]

122. Maruya, K.A.; Vidal-Dorsch, D.E.; Bay, S.M.; Kwon, J.W.; Xia, K.; Armbrust, K.L. Organic contaminants of emerging concern in sediments and flatfish collected near outfalls discharging treated wastewater effluent to the Southern California Bight. Environ. Toxicol. Chem. 2012, 31, 2683-2688. [CrossRef]

123. Beretta, M.; Britto, V.; Tavares, T.M.; da Silva, S.M.T.; Pletsch, A.L. Occurrence of pharmaceutical and personal care products (PPCPs) in marine sediments in the Todos os Santos Bay and the north coast of Salvador, Bahia, Brazil. J. Soils Sediments 2014, 14, 1278-1286. [CrossRef]

124. Klosterhaus, S.L.; Grace, R.; Hamilton, M.C.; Yee, D. Method validation and reconnaissance of pharmaceuticals, personal care products, and alkylphenols in surface waters, sediments, and mussels in an urban estuary. Environ. Int. 2013, 54, 92-99. [CrossRef]

125. Xie, H.; Hao, H.; Xu, N.; Liang, X.; Gao, D.; Xu, Y.; Gao, Y.; Tao, H.; Wong, M. Pharmaceuticals and personal care products in water, sediments, aquatic organisms, and fish feeds in the Pearl River Delta: Occurrence, distribution, potential sources, and health risk assessment. Sci. Total Environ. 2019, 659, 230-239. [CrossRef] [PubMed]

126. Long, E.R.; Dutch, M.; Weakland, S.; Chandramouli, B.; Benskin, J.P. Quantification of pharmaceuticals, personal care products, and perfluoroalkyl substances in the marine sediments of Puget Sound, Washington, USA. Environ. Toxicol. Chem. 2013, 32, 1701-1710. [CrossRef]

127. Bayen, S.; Estrada, E.S.; Juhel, G.; Kit, L.W.; Kelly, B.C. Pharmaceutically active compounds and endocrine disrupting chemicals in water, sediments and mollusks in mangrove ecosystems from Singapore. Mar. Pollut. Bull. 2016, 109, 716-722. [CrossRef] [PubMed]

128. Lara-Martín, P.A.; González-Mazo, E.; Petrovic, M.; Barceló, D.; Brownawell, B.J. Occurrence, distribution and partitioning of nonionic surfactants and pharmaceuticals in the urbanized Long Island Sound Estuary (NY). Mar. Pollut. Bull. 2014, 85, 710-719. [CrossRef]

129. Stewart, M.; Olsen, G.; Hickey, C.W.; Ferreira, B.; Jelić, A.; Petrović, M.; Barcelo, D. A survey of emerging contaminants in the estuarine receiving environment around Auckland, New Zealand. Sci. Total Environ. 2014, 468-469, 202-210. [CrossRef]

130. Montesdeoca-Esponda, S.; Sosa-Ferrera, Z.; Santana-Rodríguez, J.J. Combination of microwave-assisted micellar extraction with liquid chromatography tandem mass spectrometry for the determination of fluoroquinolone antibiotics in coastal marine sediments and sewage sludges samples. Biomed. Chromatogr. 2012, 26, 33-40. [CrossRef] [PubMed]

131. Montesdeoca-Esponda, S.; Sosa-Ferrera, Z.; Santana-Rodríguez, J.J. Microwave-assisted extraction combined with on-line solid phase extraction followed by ultra-high-performance liquid chromatography with tandem mass spectrometric determination of benzotriazole UV stabilizers in marine sediments and sewage sludges. J. Sep. Sci. 2013, 36, 781-788. [CrossRef]

132. De la Guardia, M.; Armenta, S. Greening Sample Treatments; Elsevier: Amsterdam, The Netherlands, 2011 ; Volume 57.

133. Kataoka, H. Pharmaceutical analysis. Sample preparation. In Encyclopedia of Analytical Science; Elsevier: Amsterdam, The Netherlands, 2019; pp. 231-255; ISBN 9780081019832.

134. Aalizadeh, R.; Nika, M.C.; Thomaidis, N.S. Development and application of retention time prediction models in the suspect and non-target screening of emerging contaminants. J. Hazard. Mater. 2019, 363, 277-285. [CrossRef] [PubMed]

135. Creusot, N.; Casado-Martinez, C.; Chiaia-Hernandez, A.; Kiefer, K.; Ferrari, B.J.D.; Fu, Q.; Munz, N.; Stamm, C.; Tlili, A.; Hollender, J. Retrospective screening of high-resolution mass spectrometry archived digital samples can improve environmental risk assessment of emerging contaminants: A case study on antifungal azoles. Environ. Int. 2020, 139, 105708. [CrossRef]

136. Schymanski, E.L.; Singer, H.P.; Slobodnik, J.; Ipolyi, I.M.; Oswald, P.; Krauss, M.; Schulze, T.; Haglund, P.; Letzel, T.; Grosse, S.; et al. Non-target screening with high-resolution mass spectrometry: Critical review using a collaborative trial on water analysis. Anal. Bioanal. Chem. 2015, 407, 6237-6255. [CrossRef] [PubMed]

137. Schymanski, E.L.; Jeon, J.; Gulde, R.; Fenner, K.; Ruff, M.; Singer, H.P.; Hollender, J. Identifying small molecules via high resolution mass spectrometry: Communicating confidence. Environ. Sci. Technol. 2014, 48, 2097-2098. [CrossRef] [PubMed]

138. Comtois-Marotte, S.; Chappuis, T.; Vo Duy, S.; Gilbert, N.; Lajeunesse, A.; Taktek, S.; Desrosiers, M.; Veilleux, É.; Sauvé, S. Analysis of emerging contaminants in water and solid samples using high resolution mass spectrometry with a $Q$ Exactive orbital ion trap and estrogenic activity with YES-assay. Chemosphere 2017, 166, 400-411. [CrossRef]

139. Huang, Z.; Lee, H.K. Micro-solid-phase extraction of organochlorine pesticides using porous metal-organic framework MIL-101 as sorbent. J. Chromatogr. A 2015, 1401, 9-16. [CrossRef] [PubMed]

140. Benedé, J.L.; Anderson, J.L.; Chisvert, A. Trace determination of volatile polycyclic aromatic hydrocarbons in natural waters by magnetic ionic liquid-based stir bar dispersive liquid microextraction. Talanta 2018, 176, 253-261. [CrossRef] [PubMed] 